\title{
Infrastructure for collaborative science and societal applications in the Columbia River estuary
}

\author{
António M. BAPTISTA $(\bowtie)^{1,2}$, Charles SEATON ${ }^{1,2}$, Michael P. WILKIN ${ }^{1,3}$, Sarah F. RISEMAN ${ }^{1,2}$, \\ Joseph A. NEEDOBA ${ }^{1,2}$, David MAIER ${ }^{1,4}$, Paul J. TURNER ${ }^{1,2}$, Tuomas KÄRNÄ ${ }^{1,2}$, Jesse E. LOPEZ ${ }^{1,2}$, \\ Lydie HERFORT ${ }^{1,2}$, V.M. MEGLER ${ }^{1,4}$, Craig McNEIL ${ }^{1,5}$, Byron C. CRUMP ${ }^{1,6,7}$, \\ Tawnya D. PETERSON ${ }^{1,2}$, Yvette H. SPITZ ${ }^{1,6}$, Holly M. SIMON ${ }^{1,2}$ \\ 1 NSF Science and Technology Center for Coastal Margin Observation \& Prediction \\ 2 Oregon Health \& Science University, Portland, Oregon 97239, USA \\ 3 Oregon Health \& Science University, Astoria, Oregon 97103, USA \\ 4 Portland State University, Portland, Oregon 97201, USA \\ 5 Applied Physics Laboratory of the University of Washington, Seattle, Washington 98105, USA \\ 6 Oregon State University, Corvallis, Oregon 97331, USA \\ 7 Formerly University of Maryland Center for Environmental Studies, Maryland 21613, USA
}

(C) Higher Education Press and Springer-Verlag Berlin Heidelberg 2015

\begin{abstract}
To meet societal needs, modern estuarine science needs to be interdisciplinary and collaborative, combine discovery with hypotheses testing, and be responsive to issues facing both regional and global stakeholders. Such an approach is best conducted with the benefit of data-rich environments, where information from sensors and models is openly accessible within convenient timeframes. Here, we introduce the operational infrastructure of one such data-rich environment, a collaboratory created to support (a) interdisciplinary research in the Columbia River estuary by the multi-institutional team of investigators of the Science and Technology Center for Coastal Margin Observation \& Prediction and (b) the integration of scientific knowledge into regional decision making. Core components of the operational infrastructure are an observation network, a modeling system and a cyber-infrastructure, each of which is described. The observation network is anchored on an extensive array of long-term stations, many of them interdisciplinary, and is complemented by on-demand deployment of temporary stations and mobile platforms, often in coordinated field campaigns. The modeling system is based on finiteelement unstructured-grid codes and includes operational and process-oriented simulations of circulation, sediments and ecosystem processes. The flow of information is managed through a dedicated cyber-infrastructure, conversant with regional and national observing systems.
\end{abstract}

Received April 17, 2015; accepted July 15, 2015

E-mail: baptista@ohsu.edu
Keywords estuaries, observations, numerical modeling, cyber-infrastructure, Columbia River

\section{Introduction}

Coastal communities have a strong demographic and economic preponderance worldwide. In the United States (U.S.) alone, they consist of 123 million people ( $40 \%$ of the total population; NOAA, 2014a), generate $45 \%$ of the Gross Domestic Product and support over 51 million jobs (NOAA, 2014b). These communities rely heavily on a diverse range of services provided by coastal margins, which constitute a resource-rich but ecologically sensitive interface between land and ocean.

Essential sub-systems of coastal margins are estuaries, complex environments where transitions from fresh to marine waters often occur across steep spatial and temporal gradients. Estuaries provide economic resilience to coastal communities and deliver important ecosystem services (Barbier et al., 2011). Many estuaries are essential waterways, which are critical to local and global commerce. They are also essential migration routes or nurseries for birds, fish and shellfish, while buffering the coastal ocean from increased nutrient loads and other terrestrial contaminants. Collectively, they form a global resource of increasingly recognized significance for society (MEA, 2005; OGE, 2014).

The susceptibility of estuaries to climate change and economic development is a major ecological and socioeconomic concern (Lotze et al., 2006). Sea level rise alone 
poses a significant threat to the world's estuaries (Statham, 2012; Robinson et al., 2013; IPCC, 2014), via potential increases in flooding, salinity intrusion and disruption of aquatic ecosystems. Also, anthropogenic practices have imposed major stresses on estuaries in recent decades, such as increased nutrient loads leading to hypoxic dead zones (Diaz and Rosenberg, 2008; Howarth et al., 2011; Statham, 2012). In some estuaries, the effects of these stresses have been mitigated and even reversed through management approaches that employ best practices informed by scientific understanding; for instance, nutrient loads and dead zones have been successfully reversed in some estuaries (Diaz and Rosenberg, 2008).

However, for many estuaries, potentially drastic reductions in ecological resilience lie ahead, as expressions of climate change and local anthropogenic stresses increase. As a striking example, the 10 most populated water basins (4 in China, 3 in India, 2 in Africa, and 1 in Europe) already account for $10 \%$ of the world's Gross Domestic Product, but in 40 years this figure is projected to increase to $25 \%$ (more than Japan, Germany, and the U.S. combined; HSBC, 2012). Without effective management, this massive development poses an unprecedented threat to estuaries, with major potential for disruption of global biogeochemical cycles, of local and global ecosystem services and ultimately of human well-being.

Developing or improving science-based anticipatory capabilities that allow society to best manage estuaries is critical to a sustainable Earth, but is also challenging because estuaries are complex and highly varying ecosystems. To meet these challenges for a specific estuary, and provide a model for others, we created a distinctive scientific infrastructure that we term a collaboratory. The SATURN (Science And Technology University Research Network) collaboratory is designed to facilitate generation and open flow of information, towards enhanced scientific understanding, prediction, operation, and sustainability of the Columbia River estuary in the U.S. (Fig. 1). Here, we document the operational infrastructure of SATURN and provide brief insights into lessons learned.

\section{The study area}

\subsection{The broader context of the Columbia River basin}

The Columbia River is the largest of the North American rivers flowing into the Pacific Ocean, with daily average discharges (at Bonneville Dam, Fig. 1) ranging from $\sim 2,000 \mathrm{~m}^{3} \cdot \mathrm{s}^{-1}$ in the early fall to $\sim 15,000 \mathrm{~m}^{3} \cdot \mathrm{s}^{-1}$ during spring freshets (Fig. 2, top panel). The river basin crosses the U.S.-Canada border, and includes seven U.S. states: Idaho, Oregon, Washington, Montana, Nevada, Wyoming, and Utah. As a major economic resource for the region, the Columbia River is managed for multiple purposes: power

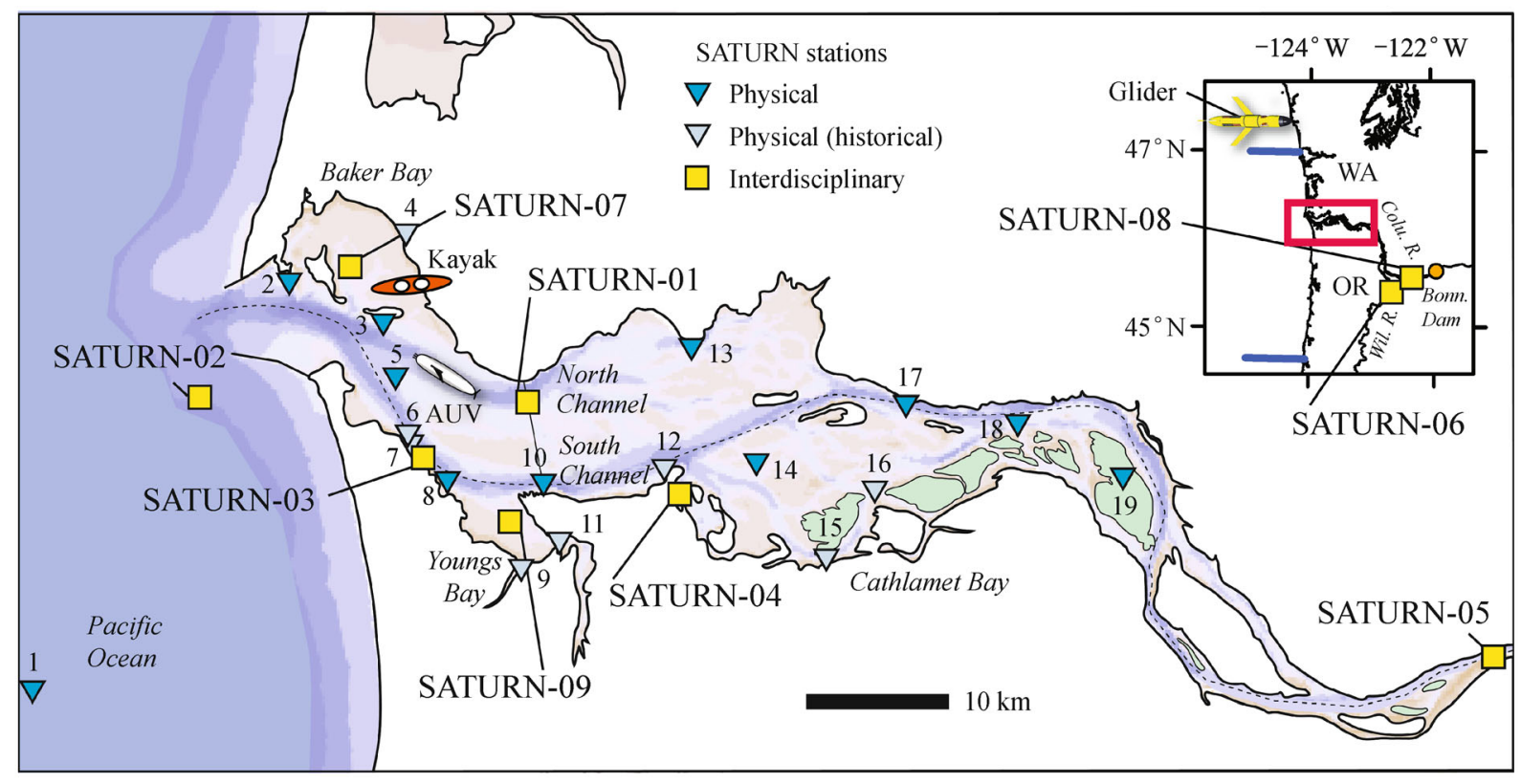

Fig. 1 The Columbia River estuary. The inset shows the full estuary, which is tidally influenced up to Bonneville Dam, and separates the states of Oregon (OR) and Washington (WA). The region of the estuary subject to ocean influence is contained in the larger map (maximum salinity intrusion is typically less than $45 \mathrm{~km}$ ). Yellow squares represent interdisciplinary endurance stations of the SATURN observation network; dark and light cyan triangles represent current and historical physical endurance stations of the same network. Illustrative symbols represent areas of typical deployment of mobile platforms: kayak, gliders, and autonomous underwater vehicles (AUVs). The blue lines in the inset are endurance observation lines of the independent but synergistic Ocean Observing Initiative (NSF, 2005). 

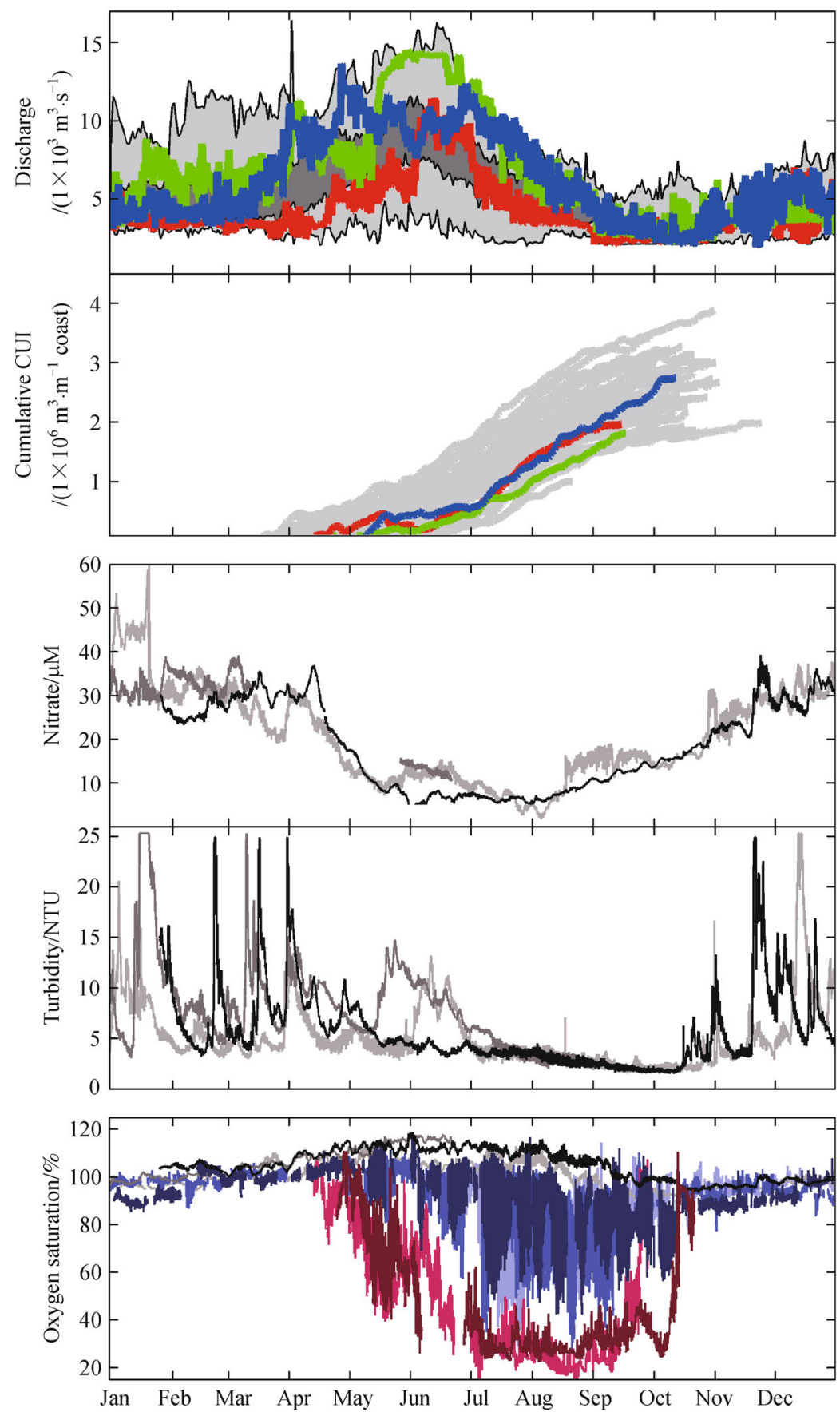

Fig. 2 Ocean and river forcing have strong seasonal and inter-annual variability. Top panel: River discharge at Bonneville Dam for a 3year period (red: 2010; green: 2011; blue: 2012), mapped against the $1996-2014$ climatology $\left(25^{\text {th }}\right.$ and $75^{\text {th }}$ percentile in dark gray; maxima and minima in lighter gray). Second panel: Cumulative Coastal Upwelling Index (CUI; red: 2010; green: 2011; blue: 2012), mapped against 1996-2014 (in gray). Third and fourth panels: Freshwater nitrate and sediment loads, respectively, at SATURN-05 for 2010-2012 (darker shades represent more recent years). Bottom panel: Oxygen saturation at the mouth of the estuary (SATURN-02, in crimson shades); the South channel (SATURN-03, in blue shades); and the tidal freshwater (SATURN-05, in gray and black). Data for the bottom panel are for 2010-2012 as available; within a same color, darker shades represent more recent years.

generation, flood risk mitigation, agricultural water supply, fisheries and navigation. Essential to these activities is the operation of major navigation and hydropower systems.
The Columbia-Snake River System is a vital waterway that supports the economies of multiple U.S. states, including Oregon and Washington (Simmons and Casa- 
vant, 2010). With deep-draft and inland components, this waterway is a major gateway for wheat and barley exports (\#1 in the U.S.) and for mineral bulk exports, wood exports and auto imports (\#1 on the U.S. West Coast). Recently deepened to $13.1 \mathrm{~m}$, the deep-draft channel extends for $166.6 \mathrm{~km}$ along the estuary and supports more than 40 million tons of cargo per year, valued at $\$ 17$ billion U.S. dollars. The inland river system, mostly upstream of the estuary, supports 10 million tons of cargo per year, valued at $\$ 3$ billion U.S. dollars annually.

The Federal Columbia River Power System is a network of 31 federally owned U.S. dams managed for hydropower production and flood protection. At $\sim 22,500 \mathrm{MW}$ of maximum generating capacity ( $\sim$ over a third of the total U.S. hydroelectric capacity), these dams are the foundation of the Pacific Northwest power supply and also provide power to other U.S. states and Canada. In spite of the large number of U.S. dams, the storage capacity of the river is largely in Canada. The 1964 U.S.-Canada Columbia River Treaty, which regulates the access to that storage capacity by the U.S., is up for review in the 2014-2024 timeframe. While in its original form it focused only on power generation and flood protection, a revised Treaty will likely also address ecosystem function (U.S. Entity, 2013).

Ecosystem function is already a major consideration in the operation of both the Columbia-Snake River System and the Federal Columbia River Power System. Of particular significance, four Pacific salmon stocks are listed as endangered and thirteen as threatened under the Endangered Species Act (ESA). ESA-mandated Biological Opinions set specific guidance for salmon protection and recovery that affects all development activities in the Columbia River basin. Also of direct relevance to salmon protection and recovery is the 1855 Columbia Basin Treaties between the U.S. and the Umatilla, Nez Perce, Yakama and Warm Springs which granted those Native American tribes permanent fishing rights in their reservations and accustomed lands; the latter collectively represents approximately a quarter of the basin's area.

\subsection{The Columbia River estuary}

The Columbia River estuary serves as a biogeochemical buffer between river and ocean and offers important transitional habitat for fish and birds. Seasonal upwelling (Fig. 2, second panel) from the California Current influences estuarine conditions through tidal exchange, and results in the transport of deep-ocean waters to the estuary during the summer months. These waters are relatively rich in nutrients (Roegner et al., 2011a), low in oxygen (Roegner et al., 2011b; also, bottom panel of Fig. 2) and $\mathrm{pH}$, and high in carbon dioxide. The estuary is limited upstream by the Bonneville Dam in the Columbia River ( 160 km upstream of the mouth) and by the Willamette Falls in the Willamette River, a major tributary.
Freshwater loads of sediments and nutrients are largest from late autumn through early spring (Fig. 2, third and fourth panels).

The influence of the estuary extends along the continental shelf through a plume that reaches north to British Columbia or south to California, depending on the prevailing winds (Barnes et al., 1972; Liu et al., 2009; Burla et al., 2010a; Hickey et al., 2010). By contrast, the chemical estuary, defined by the presence of salinity upstream of the mouth, is limited to $\sim 45 \mathrm{~km}$ (Chawla et al., 2008), with actual extent dependent primarily on river flow and tidal conditions.

It is common to refer to the Columbia River estuary as a river-dominated mesotidal estuary. More specifically, the chemical estuary operates across four physical estuarine regimes: salt wedge, time-dependent salt-wedge, highly stratified and partially mixed. Each regime corresponds to a specific pairing of river flows and tide ranges, and has distinctive stratification and mixing characteristics.

Generally shallow, the chemical estuary is cut deeply by two major channels (Fig. 1): the South Channel, which is maintained for deep-draft navigation and the North Channel, which is unmanaged. Both channels are ecologically important, for instance as conduits of ocean influences into the estuary (Roegner et al., 2011a, b), as migration corridors for juvenile Pacific salmon (Bottom et al., 2005) and as loci for seasonal Mesodinium spp. blooms (Herfort et al., 2011a). However, each channel is dynamically distinct: the South Channel has stronger river outflow than the North Channel, less tidal transport and a less well-developed salt wedge (Chawla et al., 2008).

Also of ecological significance are four lateral bays, two of which are brackish (Baker Bay and Youngs Bay) and the other two (Cathlamet Bay and Grays Bay) primarily freshwater. Ecosystem services provided by these bays are diverse, ranging from transitional habitat for out-migrant juvenile salmon (e.g., Cathlamet Bay; Bottom et al., 2005) to seeding seasonal Mesodinium spp. blooms (e.g., Baker Bay; Herfort et al., 2011a).

As estuaries do, the Columbia River estuary provides an ecosystem service by reducing fluxes of natural and anthropogenic materials to the coastal ocean, thus functioning as a natural bioreactor. We use the term "bioreactor" (rather than the more commonly used terms "filter" or "buffer") to evoke the combination of active microbial, biogeochemical and ecological processes that result in the biogeochemical transformation of organic and inorganic materials. The term bioreactor is also a useful construct to encapsulate material and energy flows through the ecosystem, ultimately leading to food web structure and defining water quality and ecosystem health.

Because of the estuary's short residence times, many of the biogeochemical transformations in the bioreactor are hypothesized to occur in association with biological hotspots that extend water or particle residence time. 
These hotspots specifically include estuarine turbidity maxima, seasonal Mesodinium spp. blooms and intertidal zones in lateral bays. The dynamics and function of the bioreactor and its hotspots are the focus of the research of the Center for Coastal Margin Observation \& Prediction (CMOP), a multi-institutional Science and Technology Center funded by the U.S. National Science Foundation.

\section{Columbia River collaboratory}

\subsection{Concept}

Many issues of societal importance, from fisheries to shipping and power generation, require the study of estuaries. The knowledge base needed to address these issues is enabled or enhanced by high-resolution, longterm time series of observations, especially when coupled with computational models that extend the range of observations. The term estuarine collaboratory captures the open and collaborative infrastructure that allows the knowledge base for an estuary to grow from study to study and application to application.

We view an estuarine collaboratory as a networked integration of sensors and platforms, models, and information flows, designed to enable diverse communities of practice to interact productively with reduced geographic, disciplinary or institutional barriers. The term communities of practice refers to groups of people who share a concern or interest (such as the environmentally sound operation of the Federal Columbia River Power System), and who deepen their knowledge and expertise (e.g., ability to reach consensus on controversial issues at the power-systemsalmon-conservation interface) by interacting and sharing information on a sustained basis (Lave and Wenger, 1991; Wenger, 1998).

SATURN is an implementation of the collaboratory concept (Baptista et al., 2008; Baptista, 2015). It is designed to support interdisciplinary research in the Columbia River estuary, as well as to support regional decisions on the appropriate balance for the use of the estuary and river for hydropower generation, flood protection, navigation, and nursery and migration habitat for salmon. Of particular interest is the characterization of physical and biogeochemical processes that underlay the function of the estuary, and that illuminate the estuary's variability and susceptibility to changes in global climate and in operation of the Federal Columbia River Power System and the Columbia-Snake River System.

The successful implementation of SATURN is predicated on the open flow of information, which requires a supporting cyber-infrastructure. It is also predicated on the availability and integration of observations and simulations, which requires an observation network and a modeling system. These three operational components of SATURN are the focus of this paper.

\subsection{SATURN observation network}

Starting in 1996, the development of the observation network was directed initially by the interest in calibrating and validating a modeling system for estuarine circulation (CORIE; Baptista et al., 1999, 2008; Baptista, 2006). The network consisted of several real-time stations measuring physical variables: salinity, temperature, water levels and, at a few stations, velocity profiles. Driven by the CMOP focus on the Columbia River estuary as a river-dominated estuarine bioreactor, the SATURN network underwent fundamental changes after 2008 (Fig. 3). It now encompasses both endurance stations and a pioneer array (both defined and described below), and has an interdisciplinary focus with a spectrum of physical and biogeochemical sensors deployed.

\subsubsection{Real-time endurance stations}

Endurance stations provide long-term, real-time, highresolution time series at fixed locations. Most stations are concentrated in the chemical estuary, but some are in the tidal freshwater, the near-field plume or the continental shelf (Fig. 1). In the estuary, stations are located primarily along the main channels, to characterize large-scale patterns of estuarine flow and transport. These locations were chosen based on an empirical understanding of estuarine dynamics, and re-affirmed through a formal network optimization study (Frolov et al., 2008). Selected estuarine stations are also located in ecologically important lateral bays: Cathlamet Bay, Youngs Bay, and Baker Bay, each exposed to distinct ocean influences.

Some of the SATURN stations (represented by dark cyan triangles in Fig.1) remain strictly physical in terms of their sensor suites, typically with single-depth measurements of salinity and temperature. They constitute a useful reference for calibration and validation of circulation models (e.g., Baptista et al., 2005). However, nine stations now also have interdisciplinary sensor packages, and form the core of the network. These stations are named SATURN- $n n$, with $n n$ assigned sequentially in order of the date of initiation of their interdisciplinary data streams. Some SATURN- $n n$ stations (e.g., SATURN-01, -03 and -04) have replaced collocated (or nearly collocated) physical stations, in which case relevant legacy physical data is available prior to inception of the interdisciplinary station.

Most interdisciplinary stations are distinctive in design (Fig. 4) and purpose. From the perspective of design, three stations are particularly noteworthy: SATURN-01 is a vertical profiler and SATURN-03 and -04 are field laboratories with a multi-depth in-water pumping system. SATURN-01 (unique in its ability to capture the vertical structure, Fig. 5) and SATURN-03 characterize the transport and mixing in, respectively, the North and South channels of the chemical estuary. SATURN-05, 

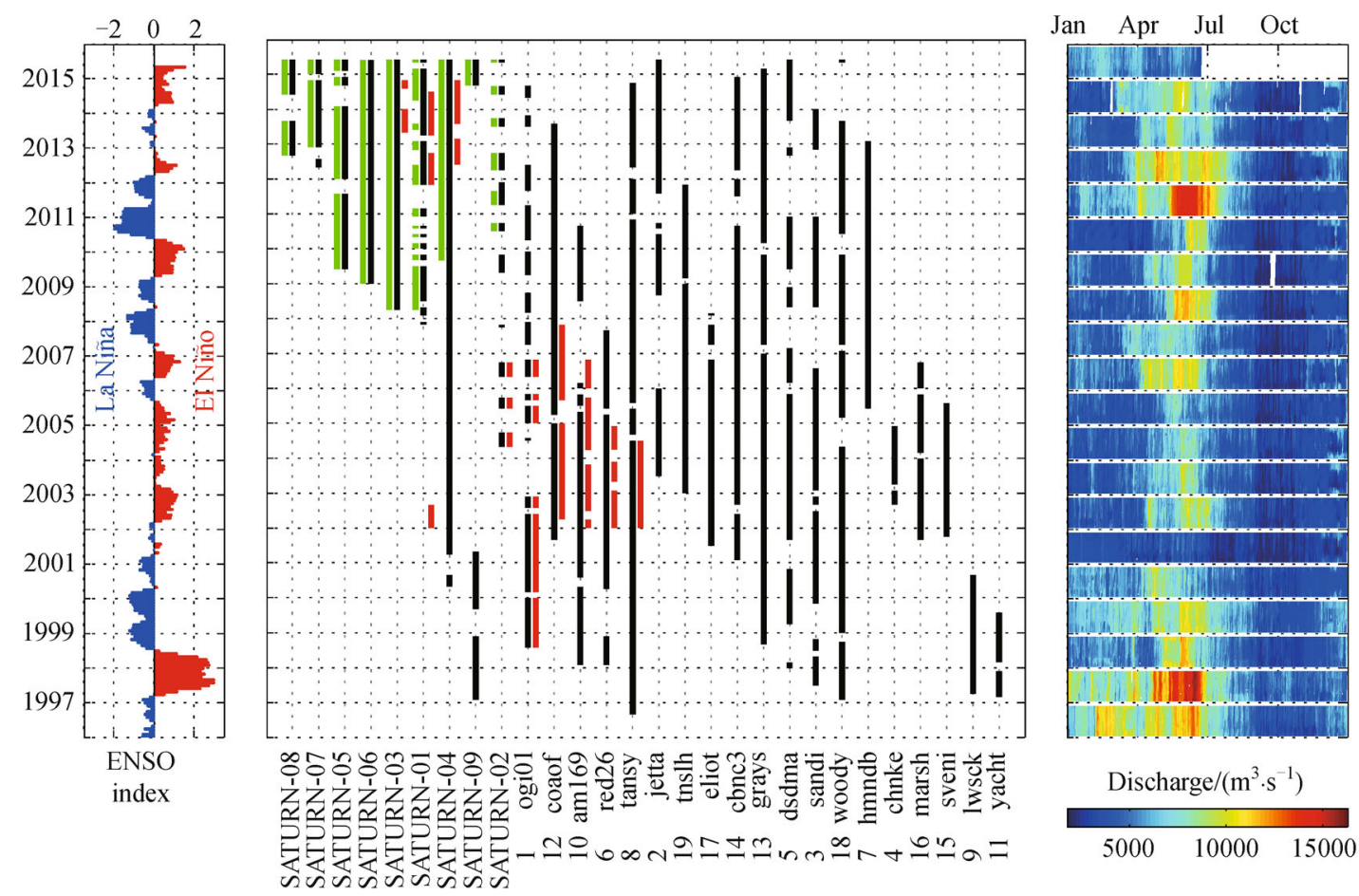

Fig. 3 Overview of the evolution of the endurance stations of the observation network, contextualized by ocean processes (via the El Niño-Southern Oscillation [ENSO] index) and river discharges at Bonneville Dam. For each station, periods of data collection are represented in black (scalar physical variables), red (vertical profiles of velocity) and green (interdisciplinary scalar variables). Numbers preceding physical stations correspond to numbering in Fig. 1.

-06 , and -08 characterize river inputs (e.g., Fig. 2, third and fourth panels). SATURN-04, -09, and -07 characterize exchanges between the estuary and progressively more ocean-influenced brackish lateral bays (Cathlamet Bay, Youngs Bay, and Baker Bay, respectively). SATURN-02 helps characterize estuary-shelf exchanges (e.g., Fig. 2, bottom panel).

Sensor composition varies per station, as shown in Fig. 6. However, all SATURN- $n n$ stations measure the same set of baseline variables ${ }^{1)}$ : temperature, salinity (derived from conductivity), dissolved oxygen, turbidity or backscatter, chlorophyll a fluoresence, colored dissolved organic matter (CDOM) and - at some sites - the fluorescence of the algal pigment phycoerythrin. Other parameters measured with regularity at some of these stations include velocity profiles (at SATURN-01, -02, -03, and -04), nitrate (at SATURN-01, -02, -03, -04, -05, and -08), $\mathrm{pH}$ and $\mathrm{pCO}_{2}$ (at SATURN-03 and -04), atmospheric variables (air temperature, solar radiation and wind speed and direction at SATURN-02 and a physical station, Desdemona Sands) and fluorescence quantum yield (at SATURN-01 and -03). Episodically, specialty instrumentation is also deployed at the SATURN-03 and -04 "field laboratories," and benefits from physical and biogeochemical contextualization by the endurance sensors available at those stations. Examples of such specialty instrumenta- tions are the Environmental Sample Processor (ESP; Scholin, 2013), a technology developed at the Monterrey Bay Aquarium Research Institute that we use for adaptive, autonomous sampling of microbial communities (Herfort et al., in press); and the SeaFlow (Swalwell et al., 2011), a flow cytometer developed at the University of Washington that allows continuous real-time observations of small phytoplankton populations.

The geographical extent of the river-to-ocean system leads to significant logistic challenges in the implementation of the observatory. The endurance stations in the chemical estuary and continental shelf (SATURN-01, -02, $-03,-04,-07$, and -09) are maintained by an operational field team, from a field station in Astoria, Oregon, near the mouth of the estuary. A Portland-based research team maintains SATURN-05 and -08. Since inception, SATURN-06 was developed in collaboration with the United States Geological Survey (USGS) and responsibility for that station is now fully assumed by that federal agency.

The number of physical stations has been reduced since 2008 (Fig. 3), in part because some were transformed into interdisciplinary stations, but also because some (light cyan triangles in Fig. 1) were discontinued. The design of the network calls for Acoustic Doppler Profilers (ADPs) to support physical oceanography and circulation modeling

1) If the baseline variable is relevant to that location (e.g., salinity may not be observed in purely freshwater locations). 

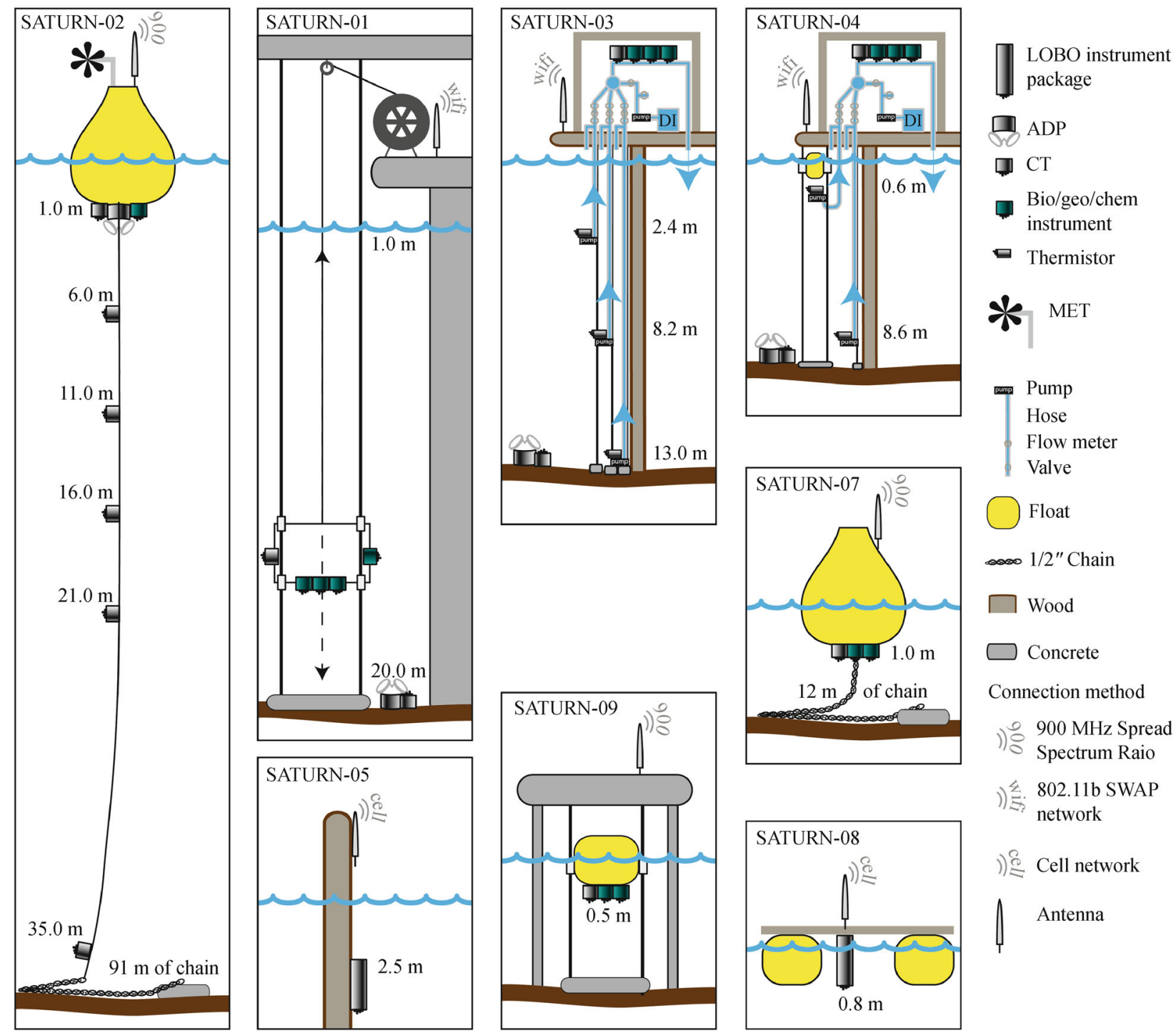

Fig. 4 Schematic representation of SATURN interdisciplinary endurance stations.

studies, and to help characterize material fluxes. ADPs were first introduced in the network in late 1998, and have been progressively restored after a 2008-2011 hiatus (Fig. 3 ). By post-2011 design, ADP locations help characterize fluxes at the North (SATURN-01) and South (SATURN03) channels, at the estuary-plume interface (SATURN-02) and between the main estuary and a freshwater lateral bay (SATURN-04).

\subsubsection{Pioneer array}

Pioneer array is a term borrowed from the Ocean Observing Initiative (NSF, 2005) and is used here to refer to assets that can be deployed on-demand to add spatial scope or spatial resolution to the endurance network, for limited time periods. The SATURN pioneer array consists of manned and unmanned mobile platforms (some of which have real-time telemetry) and re-deploy- able bottom nodes. Assets can be deployed in isolation, or in coordination within a scientifically targeted field campaign. Pioneer array assets are typically deployed with the benefit of information from endurance stations and operational models.

Unmanned mobile platforms include Slocum gliders and Remus-100 autonomous underwater vehicles (AUVs). Through the seasonal deployment of gliders (typically May-September), broad sweeps of the Washington continental shelf are conducted to characterize waters that (Hickey et al., 2010; Roegner et al., 2011a, b) serve as ocean sources for the Columbia River estuary during upwelling season. Gliders are equipped with temperature, salinity/conductivity, dissolved oxygen, optical backscatter, chlorophyll $a$ and CDOM sensors. Figure 7 illustrates a typical deployment. The coverage area is north of the Columbia River, roughly from Grays Harbor to Quinault, and the deployment is typically in a radiator pattern or 
variant thereof. The assessment of hypoxic conditions in the shelf, illustrated in the figure, is an example of the larger-scale information that is needed to interpret estuarine data such as the oxygen saturation shown in the bottom panel of Fig. 2 (for SATURN-03) and in the topmiddle panel of Fig. 5 (for SATURN-01). Glider data is also useful in support of modeling efforts, for instance by helping define ocean boundary conditions to drive estuarine biogeochemical simulations.

Two AUVs, often deployed in tandem, are used for process studies - typically in the North Channel of the estuary and occasionally across the mouth and in the nearplume. On-board sensors measure temperature, salinity/ conductivity, depth, dissolved oxygen, optical backscatter at two wavelengths $(700 \mathrm{~nm}$ and $880 \mathrm{~nm})$, fluorescence of pigments (chlorophyll $a$, phycoerythrin, and phycocyanin), CDOM, currents and bathymetry. AUV data have been instrumental in providing insight into biological hotspots such as the estuarine turbidity maxima and the Mesodinium spp. blooms. AUV data have also contributed to a stringent benchmark for the CMOP modeling system, which has resulted in novel assessments (e.g., Fig. 8) and substantial improvements of modeling skill (Kärnä et al., 2015). In turn, AUV missions are planned and interpreted with the benefit of the CMOP numerical models, by exploring in silico (not shown) alternative paths of the AUVs through forecasted fields of water velocity, density, and turbidity.
Multiple manned platforms have been integral to the SATURN pioneer array:

- The $\mathrm{R} / \mathrm{V}$ CORIE, a $20 \mathrm{ft}(6 \mathrm{~m})$ rigid-hull inflatable boat that is the workhorse for the maintenance of the in-estuary endurance stations, has been used for specialized data collection (Herfort et al., 2011b, 2012) and for AUV deployments.

- The $50 \mathrm{ft}(15 \mathrm{~m})$ training vessel M/V Forerunner, which is owned and operated by the Clatsop Community College (CCC) for mariner training programs, has been used for both serendipity data collection and targeted campaigns. CMOP installed a flow-through system (with salinity, temperature, chlorophyll $a$, and turbidity sensors) and a downward looking ADP, which perform automated data collection during CCC classes, station deployments, and other periods of serendipity vessel operation. In addition, the M/V Forerunner is used by CMOP and other scientists for short-term field campaigns (Roegner et al., 2011a, b; Bräuer et al., 2011, 2013; Peterson et al., 2013; Kahn et al., 2014) and calibration sampling near endurance stations.

- Multiple $\mathrm{UNOLS}^{1)}$ research vessels - $65 \mathrm{ft}(20 \mathrm{~m})$ R/V Clifford Barnes, $135 \mathrm{ft}(41 \mathrm{~m}) \mathrm{R} / \mathrm{V}$ Point Sur, $143 \mathrm{ft}$ $(44 \mathrm{~m}) \mathrm{R} / \mathrm{V}$ Horizon, and $177 \mathrm{ft}(53 \mathrm{~m}) \mathrm{R} / \mathrm{V}$ Wecoma and $\mathrm{R} / \mathrm{V}$ Oceanus - have been used in CMOP campaigns across the river-to-shelf continuum (Smith et al., 2010, 2012, 2013; Anderson et al., 2011; Bräuer et al., 2011,
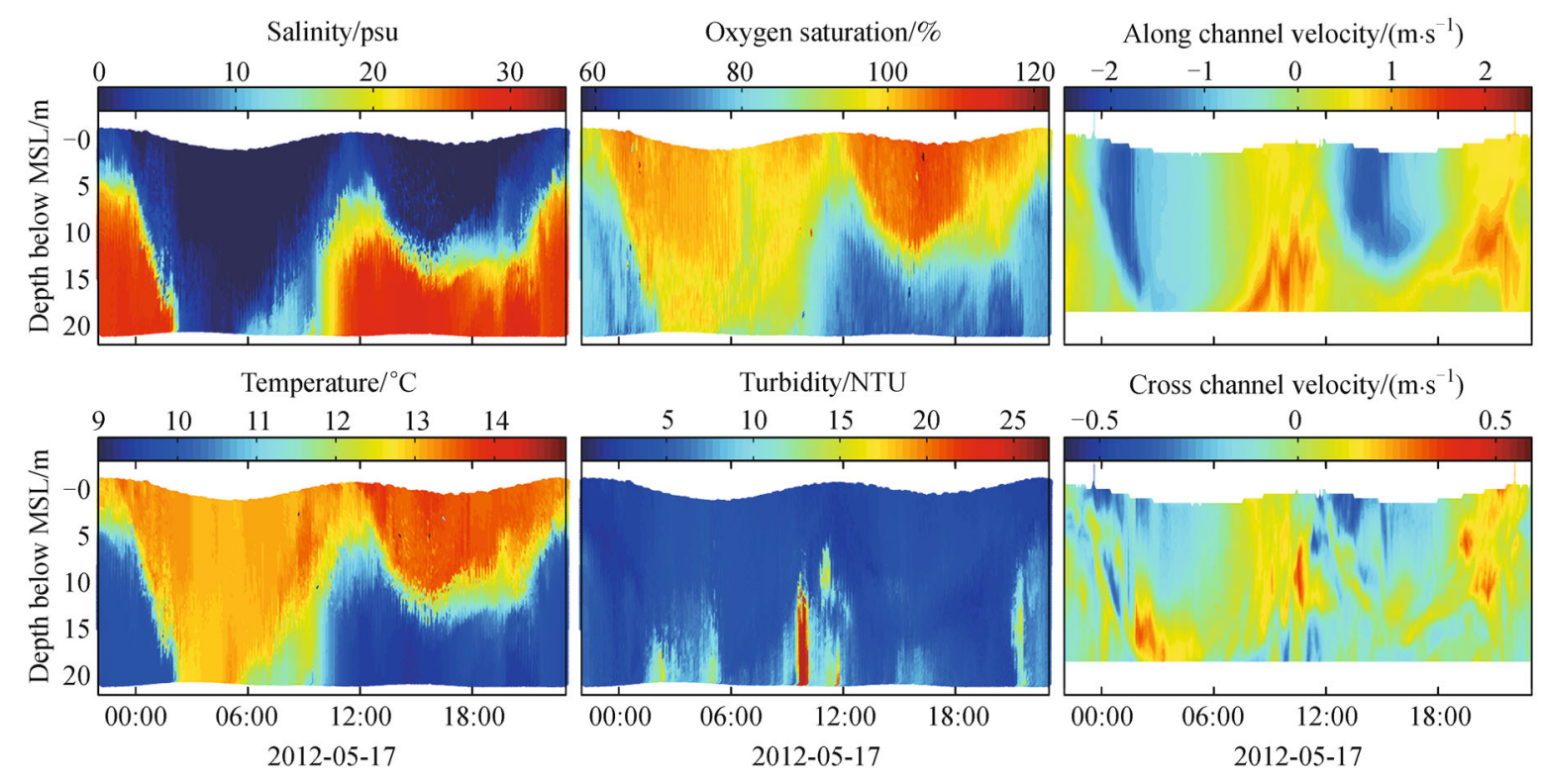

Fig. 5 Equipped with a winched profiler, SATURN-01 offers a high-resolution characterization of the vertical structure of the water column. The variability of that vertical structure over a tidal day (May 17, 2012) is illustrated here. Flow at Bonneville Dam for the period is $\sim 9,800 \mathrm{~m}^{3} / \mathrm{s}$. From left to right and top to bottom: salinity, oxygen saturation, along-channel velocity, temperature, turbidity and crosschannel velocity.

1) The University-National Oceanographic Laboratory System (UNOLS) is an organization of U.S. academic institutions and national laboratories that provides access to research ships and other oceanographic research facilities. 


\begin{tabular}{|c|c|c|c|}
\hline $\begin{array}{l}\text { SATURN-01 } \\
\text { Profiling package }\end{array}$ & $\begin{array}{l}\text { SATURN-02 } \\
\text { Ocean buoy }\end{array}$ & $\begin{array}{l}\text { SATURN-03 } \\
\text { Pumped ports }\end{array}$ & $\begin{array}{l}\text { SATURN-04 } \\
\text { Pumped ports }\end{array}$ \\
\hline Salinity * & Above surface & Salinity * & Salinity * \\
\hline Temperature & Meteorology & CDOM & CDOM \\
\hline Depth ** & PAR & Nitrate & Chlorophyll \\
\hline Chlorophyll & & Quantum yield & Dissolved oxygen \\
\hline Nitrate & Beneath buoy & Chlorophyll & Nitrate \\
\hline Turbidity & Salinity * & Dissolved oxygen & Turbidity \\
\hline CDOM & Temperature & Phycoerythrin & $\mathrm{pH}$ \\
\hline Quantum yield & Chlorophyll & Turbidity & $\mathrm{pCO}_{2}$ \\
\hline Dissolved oxygen & Turbidity & $\mathrm{pCO}_{2}$ & \\
\hline \multirow[t]{2}{*}{ Phycoerythrin } & $\mathrm{CDOM}$ & $\mathrm{pH}$ & In situ (float) \\
\hline & Nitrate & & $\mathrm{pCO}_{2}$ \\
\hline Seabed frame & Excitation spectra & In situ $(2.4 \mathrm{~m}, 8.2 \mathrm{~m}, 13 \mathrm{~m})$ & Temperature \\
\hline Salinity * & Dissolved oxygen & Temperature & \\
\hline Temperature & Velocity profile & & In situ seabed \\
\hline Velocity profile & & Intermittently deployed & Temperature \\
\hline \multirow[t]{2}{*}{ Pressure } & $6 \mathrm{~m}, 11 \mathrm{~m}, 16 \mathrm{~m}, 21 \mathrm{~m}$ & Ammonium & \\
\hline & Salinity * & Iron II & Seabed frame \\
\hline Intermittently deployed & Temperature & Nitrate & Salinity * \\
\hline \multirow[t]{2}{*}{ Susp. sediment size } & & Phosphate & Temperature \\
\hline & $35 \mathrm{~m}$ & Silicate & Pressure \\
\hline Legend & Salinity * & Susp. sediment size & Velocity profile \\
\hline \begin{tabular}{|l|l|} 
& Legena \\
& $<2008$ \\
\end{tabular} & Temperature & & \\
\hline 2008 & Dissolved oxygen & Seabed frame & Planned \\
\hline 2008 & \multirow{8}{*}{$\begin{aligned} & * \text { Derived from } \\
& \text { conductivity } \\
& * * \text { From pressure } \\
& \text { sensor }\end{aligned}$} & Salinity * & PAR \\
\hline $\begin{array}{l}2009 \\
2010\end{array}$ & & Temperature & Susp.sediment size \\
\hline $\begin{array}{l}2010 \\
2011\end{array}$ & & Dissolved oxygen & \\
\hline 2012 & & Pressure & \\
\hline 2013 & & Velocity profile & \\
\hline 2014 & & & \\
\hline & & Planned & \\
\hline & & Light attenuation & \\
\hline \multirow{2}{*}{$\begin{array}{l}\text { SATURN-05 } \\
L O B O\end{array}$} & SATURN-07 & SATURN-08 & SATURN-09 \\
\hline & Estuary buoy & $\angle O B O$ & \\
\hline Conductivity & Beneath buoy & CDOM & In situ (float) \\
\hline Temperature & Salinity * & Chlorophyll & Salinity * \\
\hline CDOM & Temperature & Oxygen & Temperature \\
\hline Chlorophyll & CDOM & Nitrate & $\mathrm{CDOM}$ \\
\hline Nitrate & Chlorophyll & Temperature & Chlorophyll \\
\hline Oxygen & Dissolved oxygen & Turbidity & Oxygen \\
\hline \multirow[t]{2}{*}{ Turbidity } & Turbidity & & Turbidity \\
\hline & Phycoerythrin & & Phycoerythrin \\
\hline Planned & Excitation spectra & & \\
\hline \multicolumn{2}{|l|}{$\mathrm{pCO}_{2}$} & & \\
\hline & Planned (above buoy) & & \\
\hline & PAR & & \\
\hline & Planned (beneath buoy) & & \\
\hline & Nitrate & & \\
\hline
\end{tabular}

Fig. 6 Sensors deployed at the interdisciplinary SATURN endurance stations, colored by year of initial deployment.

2013; Fortunato and Crump, 2011; Herfort et al., 2011b, 2012; DeLorenzo et al., 2012; Fortunato et al., 2012, 2013; Maier et al., 2012; Durkin et al., 2013; Evans et al., 2013; Gilbert et al., 2013; Peterson et al., 2013; Kahn et al., 2014). For campaign details, see stccmop.org/research/ cruise.

- A kayak, instrumented with the same baseline sensors as the SATURN- $n n$ endurance stations (Rathmell et al.,
2013), was deployed multiple times in Baker Bay in 2012 and 2013, to capture spatial variability in that shallow lateral bay. For data, see stccmop.org/datamart/observation_network/kiviuq.

Bottom nodes, instrumented with at least an upward looking ADP and a conductivity-temperature-depth (CTD) sensor, have been deployed for weeks to months, when temporal detail is temporarily needed at locations not 

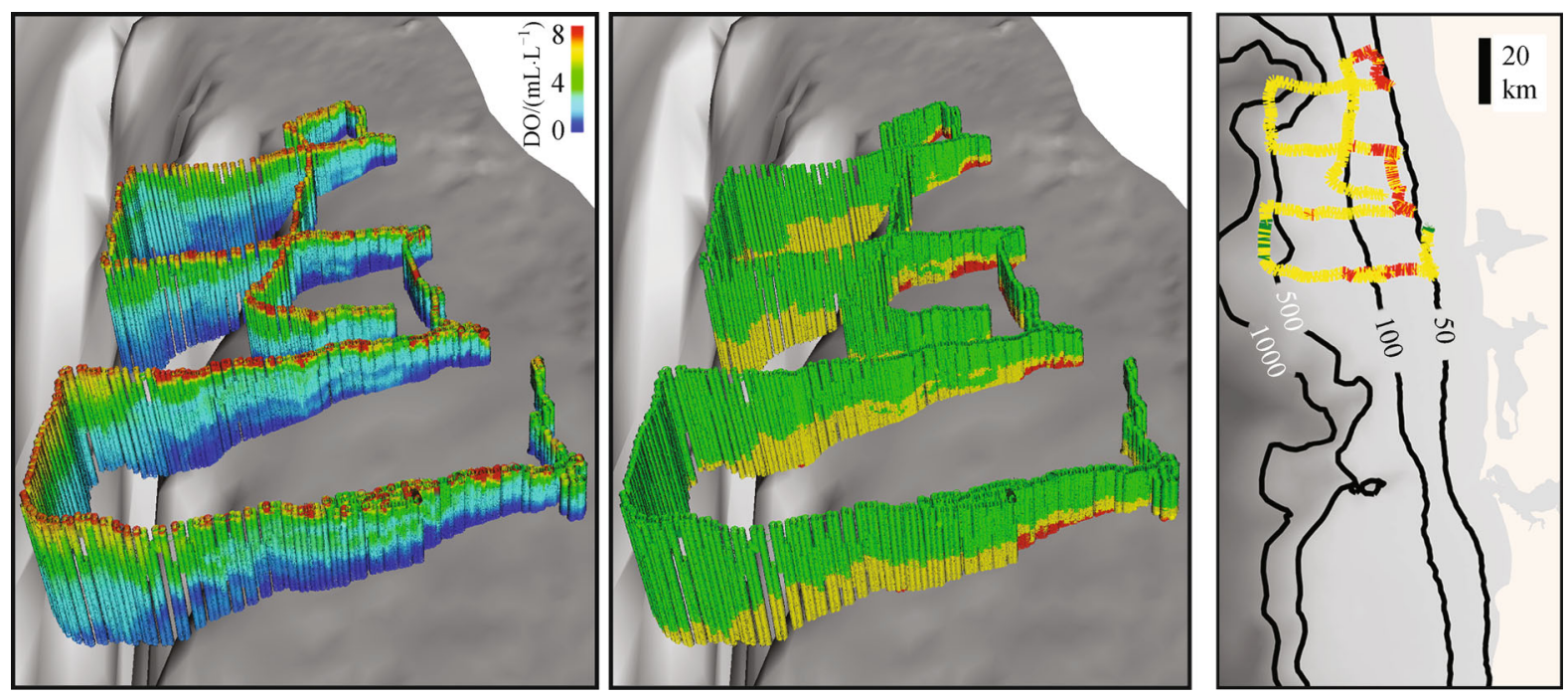

Fig. 7 Assessment of hypoxic conditions in the Washington continental shelf, based on a glider deployment for July 23-August 21, 2009. Left panel: $3 \mathrm{D}$ view of dissolved oxygen (DO). Middle panel: $3 \mathrm{D}$ view of hypoxia, where red is severe hypoxia $(\mathrm{DO} \leqslant 0.5 \mathrm{~mL} / \mathrm{L})$; yellow is mild hypoxia $(0.5<\mathrm{DO} \leqslant 1.4 \mathrm{~mL} / \mathrm{L})$; and green is oxygenated water $(\mathrm{DO}>1.4 \mathrm{~mL} / \mathrm{L})$. Right Panel: Plan view of glider path, showing the spatial extent of hypoxia at maximum dive depth. The Columbia River estuary is at the lower right (southeast) edge, with Willapa Bay and Grays Harbor to the north. See stccmop.org/datamart/observation_network/glider for additional glider data.
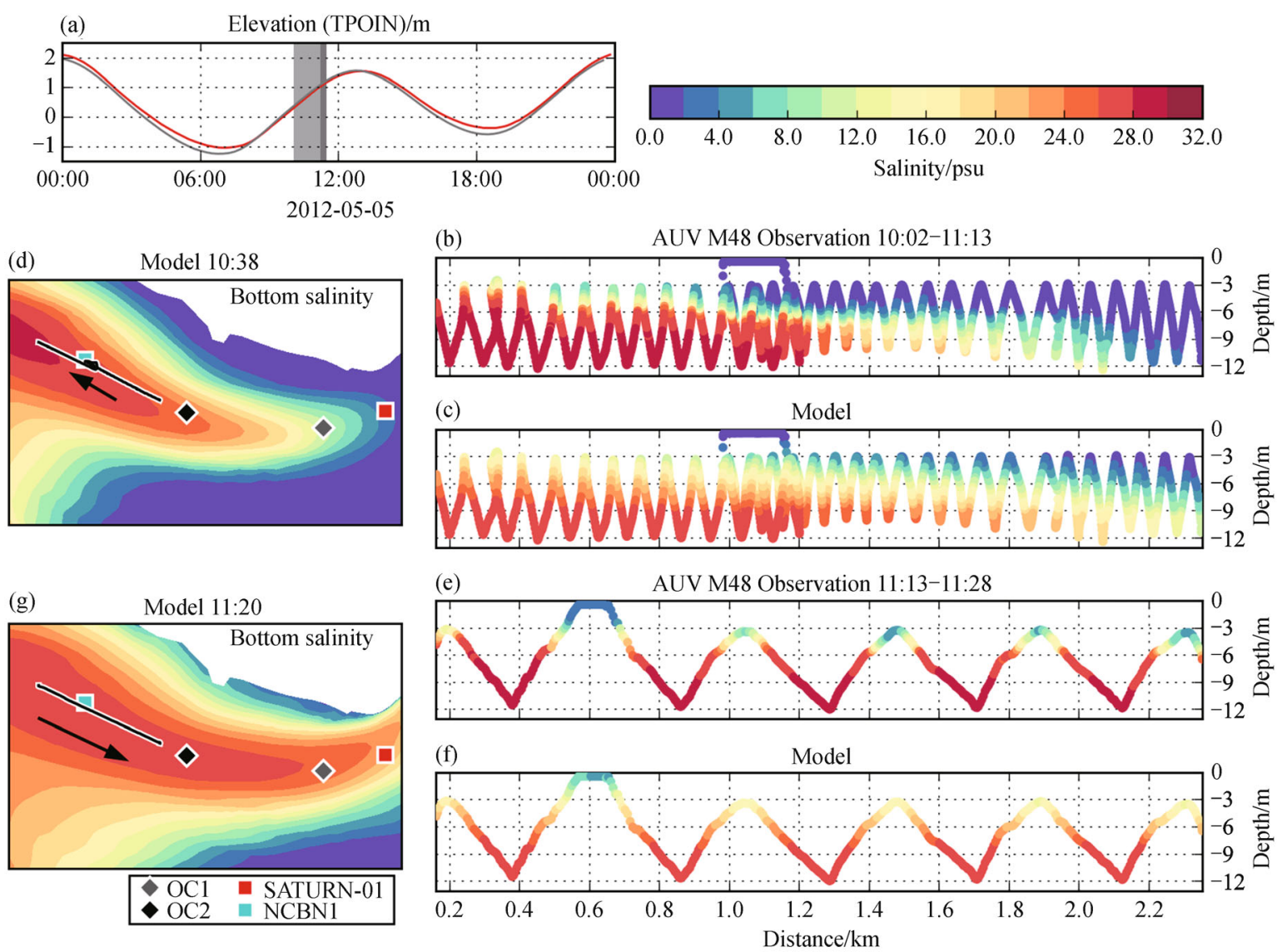

Fig. 8 Salinity data (panels (b) and (e)) collected during an AUV mission in the North Channel of the estuary, in May 2012, compared with model results (panels (c) and (f)). Panels (d) and (g) show the horizontal extent of the corresponding AUV tracks, superimposed on modeled bottom salinity fields. As typical in our operations, AUV deployments were limited to periods of flood and high water slack (see panel (a)) for logistical reasons. Also as typical, AUV missions were coordinated with other assets: a vessel, occupying either station OC1 or OC2, and a bottom node (denoted NCBN1). SATURN-01 is also shown for geographic context. 
occupied by endurance stations. Typically, bottom node deployments have been coordinated with AUV deployments or with broader field campaigns, especially in the North Channel and in Cathlamet Bay.

Vessel-based field campaigns have been conducted both in exploratory mode (e.g., recurrent baseline sampling to explore microbial population dynamics (Smith et al., 2010; Fortunato and Crump, 2011; Fortunato et al., 2012, 2013)) and targeted at understanding specific processes or balances, such as in the August 2007 Barnes cruise focused on estuarine turbidity maxima (Bräuer et al., 2011, 2013; Herfort et al., 2011c). Vessel operations have been coordinated, as appropriate and feasible, with other assets of the observation network (e.g., Fig. 9). Importantly, the design, implementation and interpretation of field campaigns has benefited from the spatial and temporal context provided by the endurance stations and by the products of the modeling system (e.g., short-term forecasts, simulation climatologies, or targeted simulation hindcasts). The importance of this context cannot be overstated: climatological information from simulation databases has transformed design and post-campaign interpretation, and realtime and predictive in-ship information has transformed implementation. For instance, CMOP scientists addressing hypotheses related to dynamic features such as estuarine turbidity maxima or salinity intrusion are able to remove (within model and observational uncertainty) much of the guesswork involved in platform placement for data collection.

We have also conducted land-based campaigns in which SATURN-03 or SATURN-04 function as field laboratories. In these campaigns, water samples are collected or specialty instruments are deployed inside the stations, for short periods of time; data acquired through the samples and specialty instruments automatically benefit from contextualization by synoptic high-resolution time series of baseline variables, which are routinely generated by the station sensors. Of particular note are adaptive sampling strategies targeting transient estuarine events for microbial RNA and DNA analysis, triggered by turbidity or other variables measured at SATURN-03 (Herfort et al., in press). Landbased and vessel campaigns have been cross-coordinated when appropriate. As an example, the contribution of Cathlamet Bay to estuarine nutrient balances was quantified through a combination (Fig. 9, bottom panel) of vessel transects, bottom nodes and SATURN-04 operated as a field laboratory. Specifically, a high-resolution Fast Methane Analyzer (from Los Gatos Research) was operated from the station (Fig. 10) and water samples for biogeochemical and microbiological analysis were extracted, all contextualized by endurance sensors.

\subsection{SATURN modeling system}

The SATURN modeling system (henceforth Virtual Columbia River, Fig. 11) is designed to create a progressively more comprehensive and skilled multiscale description of the estuary and associated tidal freshwater and continental shelf plume. The Virtual Columbia River has helped integrate and expand understanding of how the contemporary chemical estuary functions as a dynamic ecosystem. Furthermore, it has contributed a historical perspective on past evolution of the estuary and provided assessments of future conditions under alternative scenarios of change in global climate and in regional management. Besides being a research tool, the Virtual Columbia River is also an important sciencetranslation tool, having been used over the years to support multiple management decisions by diverse stakeholders (U.S. Entity, 2013; Seaton et al., 2014).

The Virtual Columbia River is anchored on highresolution circulation simulations (Baptista et al., 2005; Burla et al., 2010a; Kärnä et al., 2015), upon which operational products are created and complementary (sediment dynamics and biogeochemical) models are built. The infrastructure for the circulation simulations integrates models, bathymetry, grids, forcing, and skill assessment strategies. Circulation simulations are conducted with 3D baroclinic circulation codes, currently SELFE (Zhang and Baptista, 2008) and in the past ELCIRC (Zhang et al., 2004) and others. SELFE solves the 3D baroclinic shallow-water equations, typically with the hydrostatic approximation (a non-hydrostatic option is also available). The primary variables are free-surface elevation, velocities, salinity and temperature. Trianglebased unstructured grids are used in the horizontal direction and hybrid vertical coordinates (a combination of terrain-following $S$ coordinates and $Z$ coordinates) are used in the vertical direction.

Multiple modeling domains have been used. Typical computational grids for circulation simulations now extend from the Bonneville Dam and Willamette Falls through a lengthy tidal freshwater and a compressed estuary into the continental shelves of Oregon and Washington (Fig. 12). The grids have higher resolution in the estuary than in the continental shelf, and more recent generations of grids tend to have overall higher resolution than older generations. Higher resolution is possible because advances in code efficiency and parallelization of SELFE (Lopez and Brown, 2014) and of access to supercomputer centers.

Key operational products are daily forecasts (e.g., Fig. 13) and multi-year simulation databases of circulation (Baptista et al., 2005; Burla et al., 2010a; Kärnä et al., 2015), the latter forming the basis for a Climatological Atlas for the estuary and plume (Fig. 14). Multiple generations of forecasts and databases are numbered sequentially, and preceded by the distinguishing letters $\mathrm{F}$ (for forecasts) and DB (for databases). Thus in Figs. 1214 , DB33 is a simulation database of a more recent generation than DB22, and F33 is a forecast of the same generation of simulation database DB33. The skill of all forecasts and simulation databases is routinely assessed 


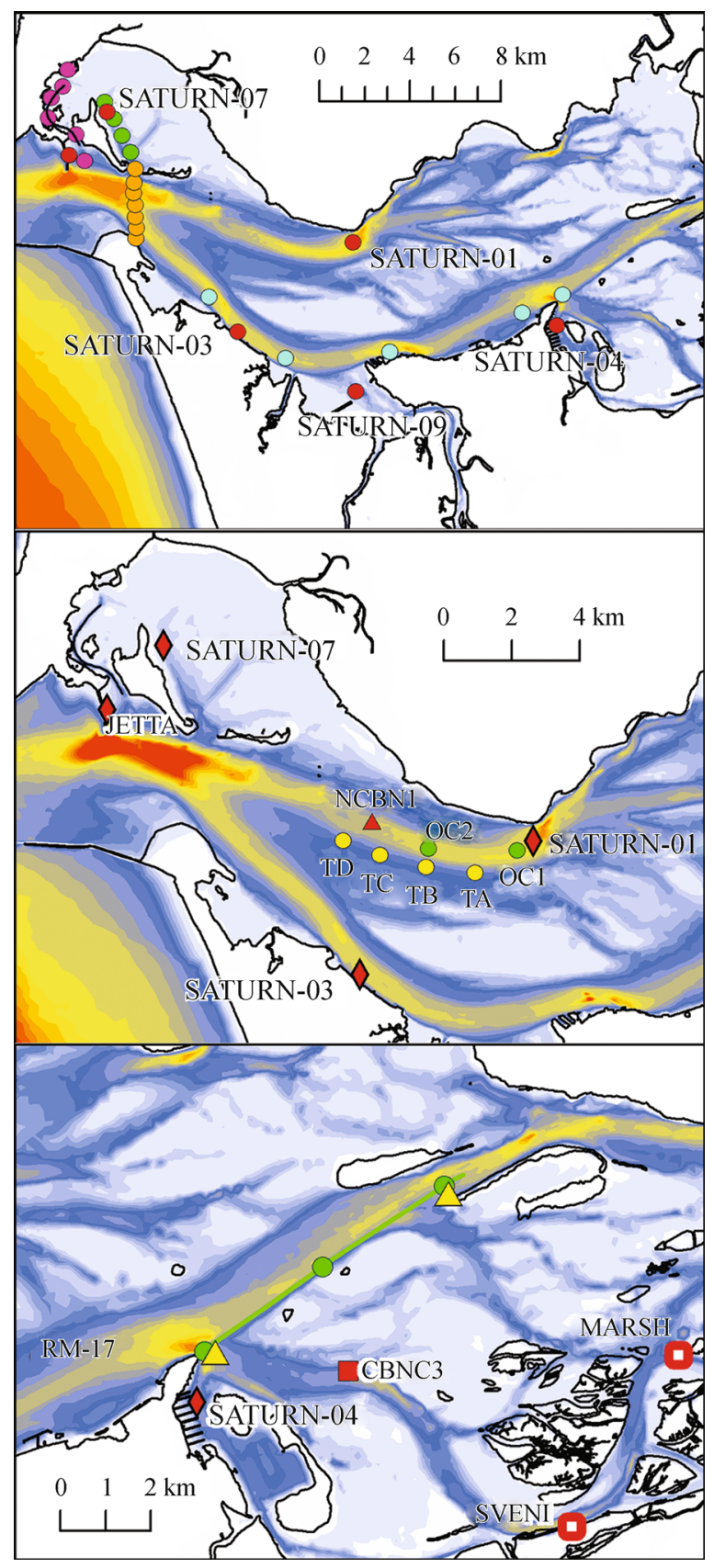

Fig. 9 Illustrative CMOP campaigns, showing water sample locations (colored circles). For context, temporary stations (red and yellow triangles) and selected endurance stations (red diamonds: interdisciplinary stations; red squares: active physical stations; hollow red squares: historical physical stations) are also shown. Bathymetry is shown in the background for all panels. Top panel: sampling pattern for monthly surveys to characterize Mesodinium spp. blooms, conducted in the M/V Forerunner or a NOAA vessel, the R/V Magister. Different colors refer to water collection lines along the South channel (cyan), across the entrance of the estuary (orange), in notable channels in Baker Bay (green and purple), at the mouth of Youngs Bay and at four endurance stations (red dots labeled SATURN-nn). Middle panel: a May 2012 campaign in the North Channel for characterization of the estuarine turbidity maxima. Green circles are sampling locations for the R/V Oceanus, and yellow circles represent acoustic nodes used for the navigation of AUVs. A bottom node was also deployed at NCBN1. Bottom panel: sampling patterns and stations for campaigns in Cathlamet Bay. The green line refers to M/V Forerunner transects, with three water-collection stations shown as green dots. Two temporary stations (yellow triangles) with bottom and surface expressions were also deployed. SATURN-04 (diamond) functioned as a field laboratory during this campaign. The acronym RM17 is at the approximate location of historical collection of water samples, which we re-visited as time allowed.

against observations (Baptista et al., 2005; Burla et al., 2010a; Kärnä et al., 2015). Observations of salinity, temperature, and velocity come primarily from the
SATURN observation network and CMOP campaigns, with tidal observations coming primarily from the National Oceanic and Atmospheric Administration (NOAA). 


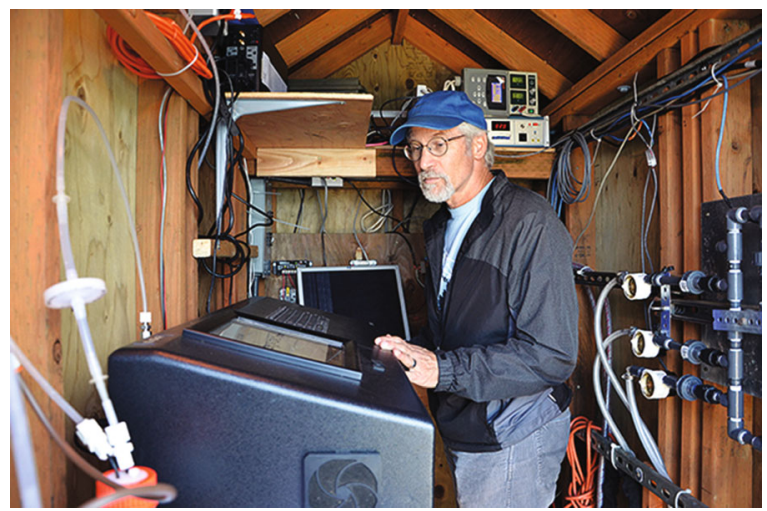

Fig. 10 CMOP investigator Fredrick G. Prahl, from Oregon State University, operates a Fast Methane Analyzer at SATURN04 during a land-based Cathlamet Bay campaign (Fig. 9, bottom panel).

Of relevance to regional applications, a "salmon filter" can be applied to circulation results to create physical metrics (ranging from salinity intrusion length and plume volume to physical habitat opportunity) identified by fisheries researchers as useful to characterize contemporary variability (Bottom et al., 2005; Burla et al., 2010b; Miller et al., 2013, 2014; Burke et al., 2014) and predict future changes in the role of the estuary, plume and shelf on the salmon lifecycle.

Critically important for CMOP research activities are emerging modeling capabilities for sediment dynamics (Lopez et al., 2012) and biogeochemistry (Spitz, 2011), all of which rely on SELFE for circulation and scalar transport. Model domains are typically reduced (estuarycentric) versions of the river-to-shelf domains used for circulation simulations. The sediment model, an adaptation of a previous implementation (Pinto et al., 2012) through enhanced computational efficiency, solves for the transport of suspended sediment and bedload, and tracks morphological changes due to erosion and deposition. The model was tested against laboratory benchmarks and is being applied to study the Columbia River estuarine turbidity maxima. Calibration and validation for the field application has relied on high-resolution turbidity data from the SATURN endurance stations and CMOP AUVs, complemented by turbidity and sediment concentration data from CMOP field campaigns.

The biogeochemical models are designed to characterize nutrient cycles and to provide insights into the estuary as a river-dominated bioreactor. At the core of the models is a flexible formulation of nutrient, bacteria, phytoplankton, zooplankton, dissolved organic matter and detritus that permits the calculation of dissolved oxygen and will ultimately address carbonate chemistry parameters. We started from an existing open-ocean conceptual model (Spitz et al., 2001), to which we introduced several adaptations customized to the nutrient cycles in the estuary, and designed to account for the influences of strong estuarine salinity gradients on marine and freshwater phytoplankton populations. The nutrient pool includes nitrogen and carbon. The water column and the exchanges at the water-air and water-benthos interfaces are included.

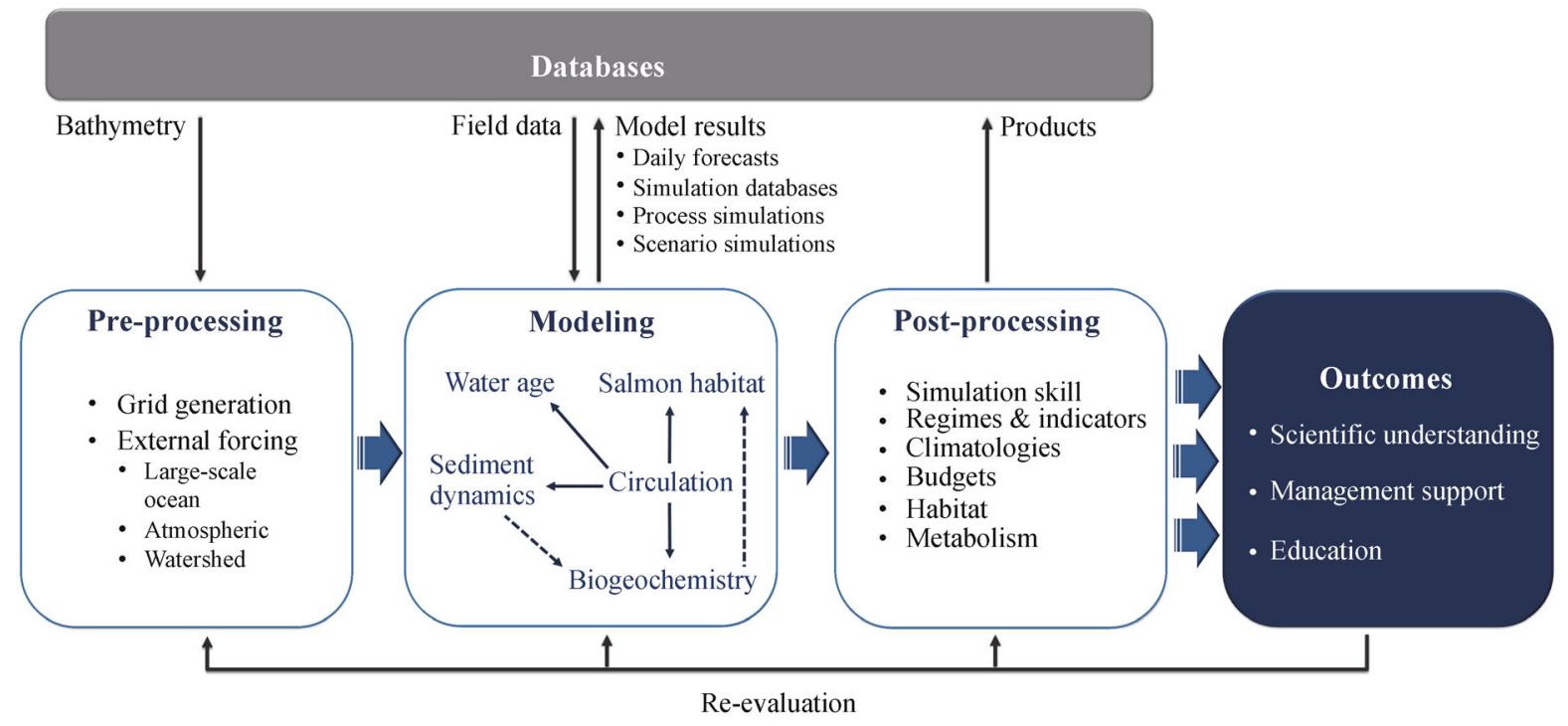

Fig. 11 Schematic of the Virtual Columbia River, which brings together consistent external forcing, coordinated codes (circulation, water age, sediment dynamics and biogeochemistry), data repositories and processing protocols, to support scientific understanding, management decisions and training activities. In the modeling box, arrows identify inter-model connectivity (with dashed arrows referring to activities in progress). Models are iteratively enhanced, a process informed by frequent assessment of simulation skill against field observations and scientific understanding. 

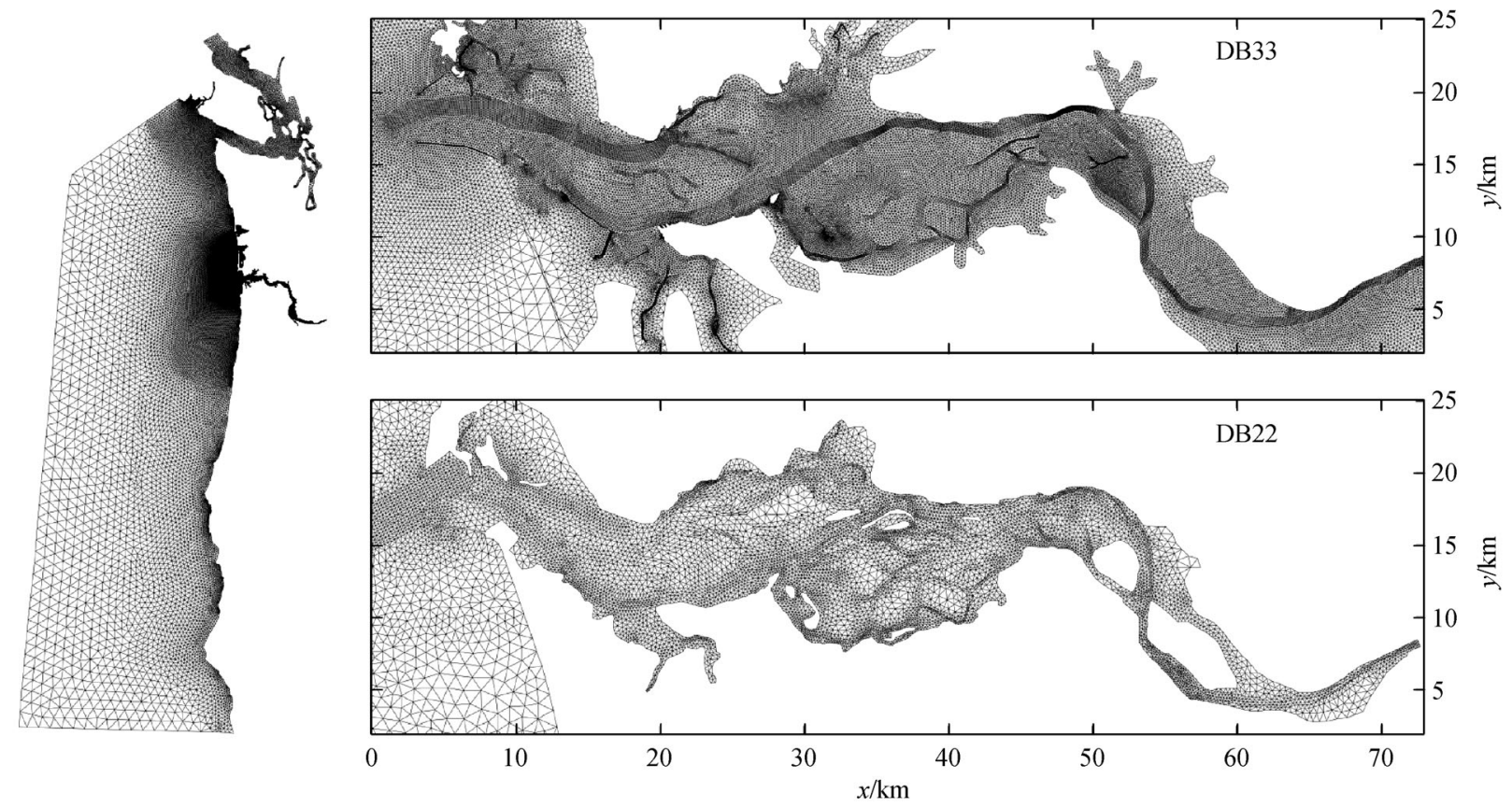

Fig. 12 Top view of illustrative computational grids of the Virtual Columbia River. The left panel shows the extent of the computational domain. The right panels are zooms on the chemical estuary of grids used in two specific simulation databases of circulation (named DB33 and DB22, respectively, with the former a newer generation simulation). The horizontal grid for the full domain consists of 109,000 triangles and 56,000 nodes for DB33, and of 39,000 triangles and 21,000 nodes for DB22. The corresponding three-dimensional grids have roughly 2.9 and 1.0 million prisms, respectively.

Light attenuation is accounted for via pre-defined water types. Blooms of Mesodinium spp. are accounted for in a special module.

After an extended period of development and assessment against interdisciplinary data from the SATURN endurance stations and CMOP cruises, the biogeochemical models are being applied to characterize Net Ecosystem Metabolism (production minus respiration) in the Columbia River. The objective is to elucidate biogeochemical processes, transformations and fluxes occurring in and across the biological hotspots targeted by CMOP science: Mesodinium spp. blooms, estuarine turbidity maxima, and lateral bays.

\subsection{Cyber-infrastructure}

The primary role of the SATURN cyber-infrastructure is to enable the free and timely flow of information among diverse producers and consumers, while also adding value to the information when appropriate (Baptista et al., 2008). There are three major information producers in the SATURN collaboratory, all of which are also (to varying degrees) information consumers: (a) sensors and platforms of the endurance stations and pioneer array; (b) model simulations; and (c) communities of practice ranging from scientists to educators, industry, emergency responders, regional managers and decision makers.

Examples of products and tools that add value to information include the Climatological Atlas, the Data Explorer and the Data Near Here (see also stccmop.org/ datamart/data_tools). The Climatological Atlas, based primarily on the Virtual Columbia River, offers insights into multiple scales of variability of the contemporary system, via statistics of various estuarine metrics and river and ocean forcing (e.g., Fig. 14). Data Near Here (Megler and Maier, 2013; also, Fig. 15) is a ranked-search engine designed to locate relevant CMOP datasets based on position, depth, time, variables and variable values. Increasingly sophisticated versions of this tool have been tested and deployed. The Data Explorer is a web-based tool for access, exploratory analysis and contextualization of SATURN observations (e.g., Fig. 16), which gives users the ability to annotate data and share analyses.

Underlying all products and tools are managed information flows (Fig. 17). Once the data is standardized and accessible, we apply several levels of quality assurance, creating multiple versions of the data. All quality levels are stored and made available. This approach allows researchers to see the effects of quality assurance procedures and apply alternative filters if desired; also, data can be 

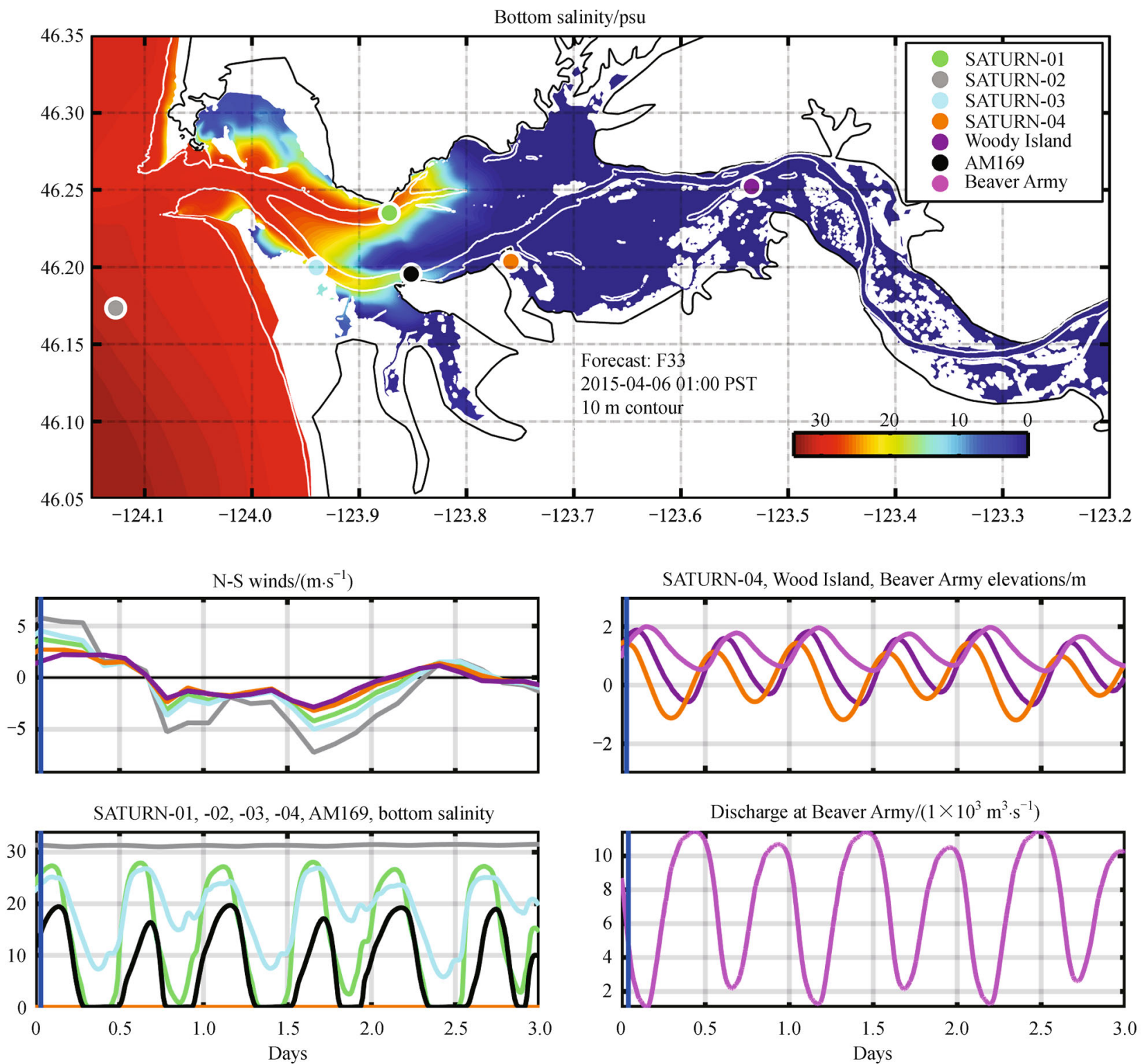

Fig. 13 The Virtual Columbia River operational products include forecasts of circulation, posted daily at stccmop.org/datamart/ virtualcolumbiariver/forecasts. Displayed here, for illustration, is a mid-ebb view of the predicted bottom salinity field in the estuary (top panel) for April 6, 2015, at 1:00AM Pacific Standard Time, complemented (bottom panels) by 3-day time series of salinity (left bottom), water levels (top right) and North-South winds (top left) at estuarine and plume stations, and of flow at Beaver Army dock (where SATURN-05 is located). Forecasts are typically done for the day of creation and for the two ensuing days.

reprocessed if better quality protocols are developed. The approach is implemented through a combination of file transfer and archiving, storage of data, creation of metadata and quality assurance metadata in a relational database, and generation of multiple iterations of a $\operatorname{NetCDF}^{1)}$ archive.

As an example, consider the real-time flow of data from a sensor at SATURN-03. A computer at the station allows data to be received from the instrumentation in real time, by a serial port (SP) reader. The serial port reader writes each raw data line from the sensor to file with a preceding time stamp line. The data from each data line is initially processed (a) to assign a depth, instrument ID and time information; (b) for some instruments, to convert engineering units into scientific units and (c) to write the data to a file. The raw (RV0) and initially processed (RV1) files are

1) NetCDF (Network Common Data Form) is a set of software libraries and self-describing machine-independent data formats, which support the creation, access and sharing of array-oriented scientific data (see unidata.ucar.edu/software/netcdf). 


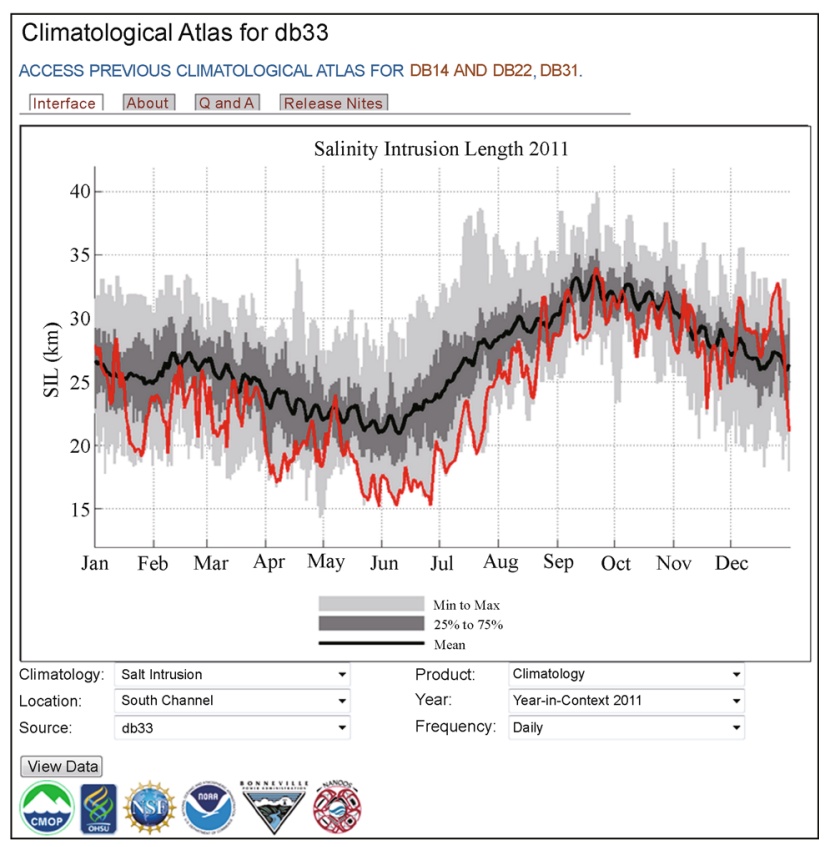

Fig. 14 A Climatological Atlas is one of the operational products of the Virtual Columbia River. Displayed here, for illustration, is the climatology of the salinity intrusion length (SIL) in the South channel of the estuary, based on a multi-year (1999-2014) simulation database. Shown are daily SIL statistics: average (in black), 25 and 75 percentiles (dark gray) and maxima and minima (lighter gray). Overlaid (in red) is SIL for 2011, a year characterized by exceptionally high discharges from mid-May through July (see Fig. 2). Because of its inverse relationship with river discharge, SIL in 2011 is extremely low for that period. See stccmop.org/datamart/virtualcolumbiariver/simulationdatabases/ climatologicalatlas for more capabilities of the Climatological Atlas. Image is a screen capture of a Climatological Atlas session.

transferred from the station computer to a central CMOP computer network in Portland, using the rsync ${ }^{1)}$ utility (with the first link being over a 802.11 wireless network, using the UNOLS Shipboard Wireless Access ProtocolSWAP, see siomail.ucsd.edu/mailman/listinfo/swap).

As the RV0 file is updated in Portland, a second processing program reads the new records and regenerates the RV1 data lines, which are then entered into a PostgreSQL ${ }^{2)}$ database in a station-specific table. A third processing program reads new lines from the database and further processes them to store in instrument-specific tables in the database. For some data sets, where data from multiple instruments is required to generate scientifically meaningful results (e.g., dissolved oxygen, where salinity and temperature from a conductivity and temperature sensor are required to convert dissolved oxygen voltage into concentration), other programs are run to pull data from the instrument-specific tables and load the results into additional instrument-specific tables.

A series of metadata tables describe which instruments are collecting data at SATURN-03 at any given time, and the metadata are used by an additional script to generate NetCDF files containing all received data that were successfully parsed, which are publicly served via THREDDS $^{3)}$ (labeled raw data or PD0). Real-time quality control is used for some variables to generate quality flags, stored in the database, and NetCDF files are generated containing data from which bad or suspect data are excluded. These files are served via THREDDS, labeled preliminary data or PD1.

The PD0 and near real-time PD1 data are ultimately further quality controlled. The quality-control process includes a visual inspection of the PD0 or PD1 data and a review of the data within a historical context as well as in relation to data from other SATURN stations. Results from pre- and post-deployment checks and sensor-specific quality assurance protocols are used to evaluate sensor calibration stability and drift. At some stations, sensor performance and stability are monitored using on-station weekly measurements of aerated DI (deionized water) and near-station CTD casts made with the M/V Forerunner. Additional quality control processes may include corrections for sensor artifacts, identification of periods of fouling and corrections for sensor drift. A final quality level (on a scale of 1 [excellent] to 5 [bad]) is assigned to the data, and metadata are generated to detail the data quality determination and any corrections applied to the data.

After full quality control of the data is completed, a third set of NetCDF files is generated and served via THREDDS labeled as verified data or PD2 (e.g., Fig. 18). The PD2 data files contain the raw data values, final data values that may have been adjusted during quality control, and data quality flags. For the THREDDS service, SATURN-03 data are divided up into monthly files.

Once sensor data from SATURN-03 are in the database and NetCDF files, they are viewable on the station page for SATURN-03, findable in Data Near Here, searched and manipulated in Data Explorer, or downloaded in several different formats.

\section{Lessons learned}

It is challenging to implement and maintain an infrastructure such as SATURN. While a comprehensive discussion is beyond the scope of this paper, Figure 3 illustrates some basic challenges for the observation

1) rsync is an open-source utility that provides fast incremental file transfer and is freely available under the GNU General Public License (see rsync.samba. org).

2) PostgreSQL is an open source object-relational database system (see postgresql.org).

3) THREDDS is a web server that provides metadata and data access for scientific datasets (see unidata.ucar.edu/software/thredds/current/tds/TDS.html). 

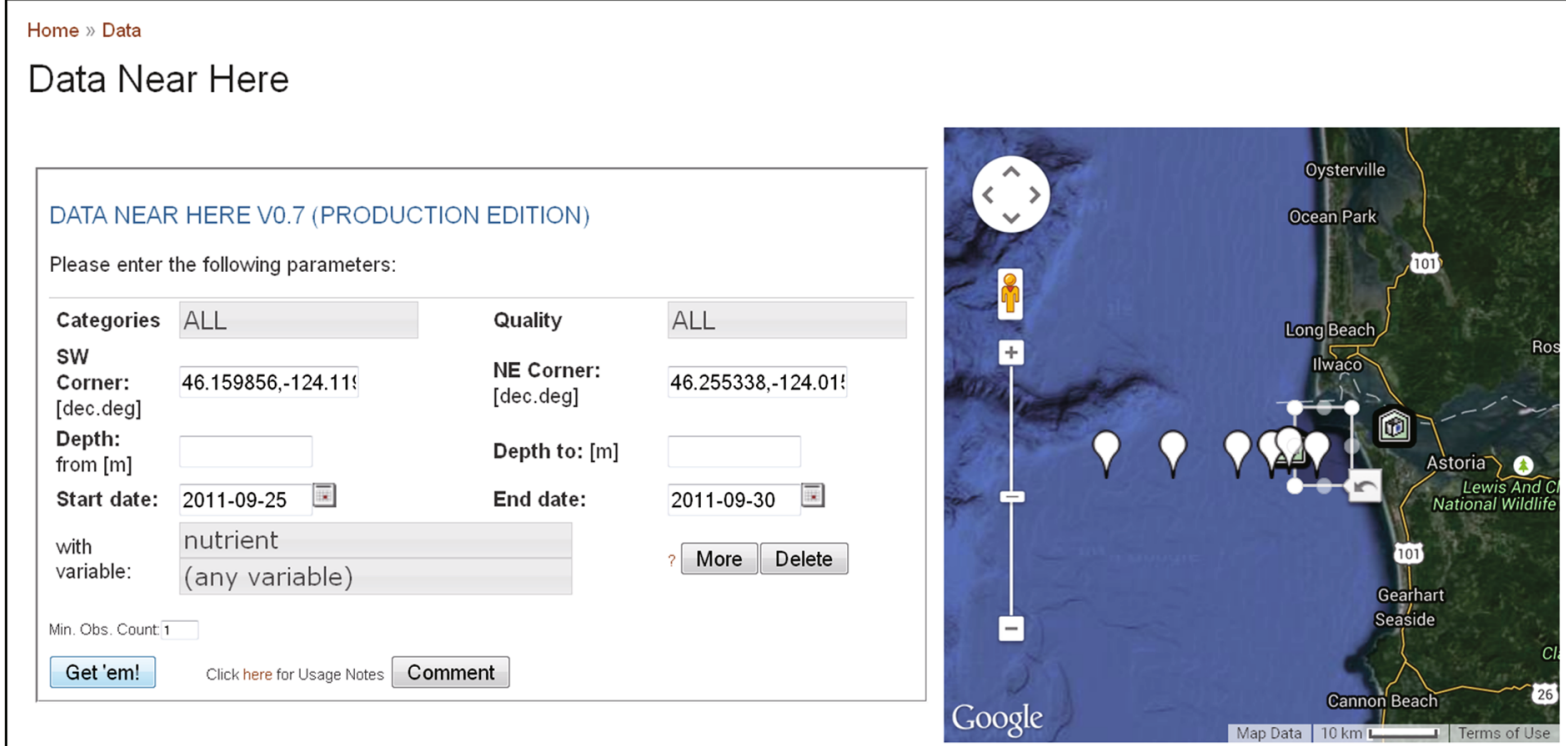

There were 50 results returned; all are listed, and 25 initially shown on map. Nutrient was found in 32 entries.

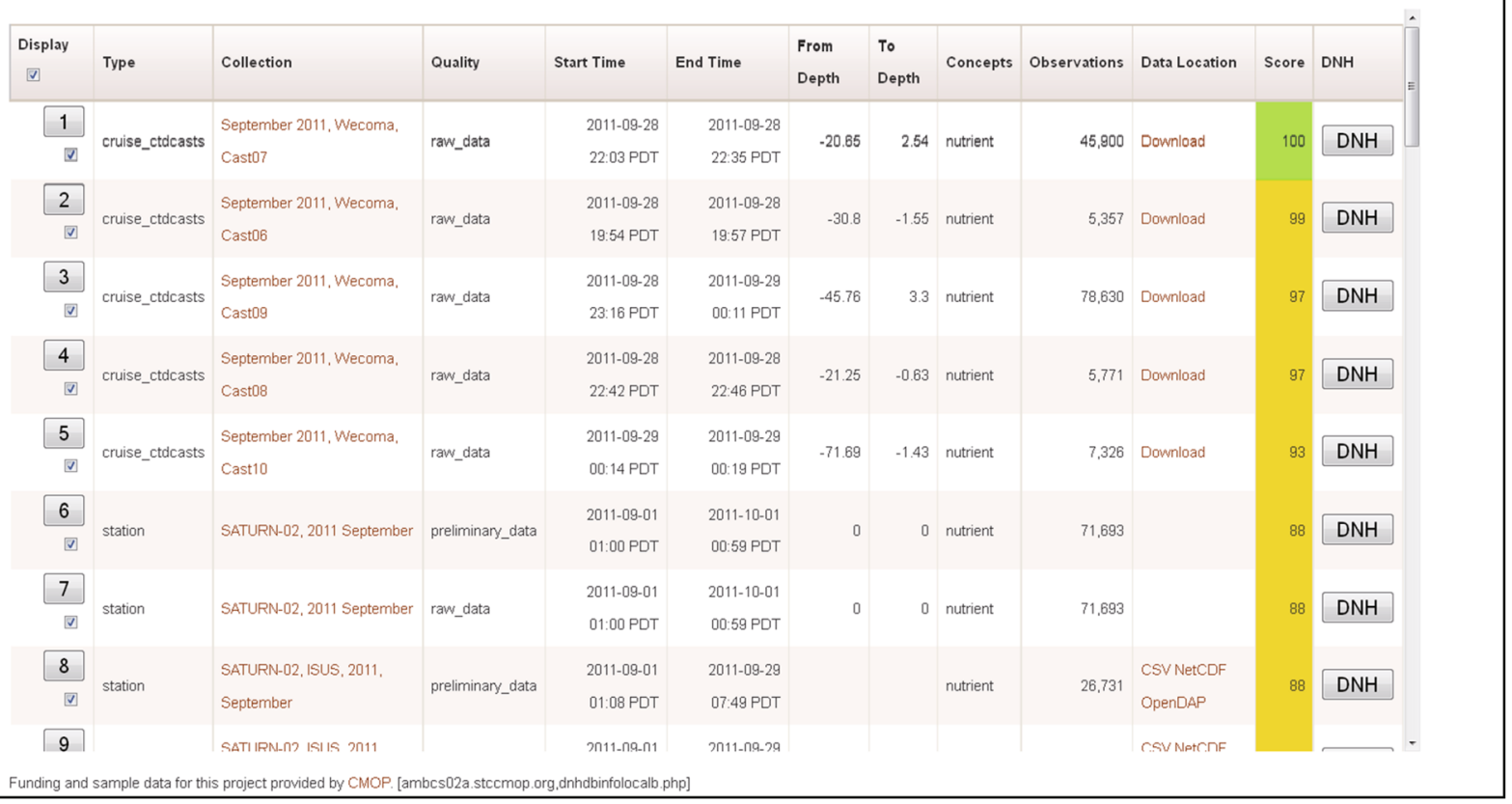

Fig. 15 Data Near Here offers a convenient means to locate SATURN data sources within or near a region (here, the adjustable box in the map) and time period (here, 2011-09-25 to 2011-09-30), for a target variable or category (here, nutrients). This particular search located 50 sources that meet or are similar to the search criteria (including the endurance stations and cruises, shown in the map), ranked (and colored, from green to yellow and red) by how close they are to the criteria. The web interface displays information about those sources. The data identified can (in whole or part) be downloaded through files, or exported to Data Explorer. For access to Data Near Here, see stccmop.org/datamart/data_near_here. Image is a screen capture of a Data Near Here session.

network. First, we note that there are extensive data gaps in the endurance stations and that, post-2008, some the original physical stations were discontinued. The gaps reflect in part the often-harsh environmental conditions in the Columbia River coastal margin. But data gaps and discontinuations also reflect the precarious balance among available resources, long-term goals and short-term priorities.
Figure 3 also shows that the inter-annual variability of the ocean (illustrated by El Niño-Southern Oscillation) and river forcing (illustrated by discharge at Bonneville Dam) occur at scales that require longer time series than currently available, both for physical and especially for biogeochemical variables. For instance, no large El Niño has yet been observed with the interdisciplinary endurance stations. The time series are not yet long enough to capture 


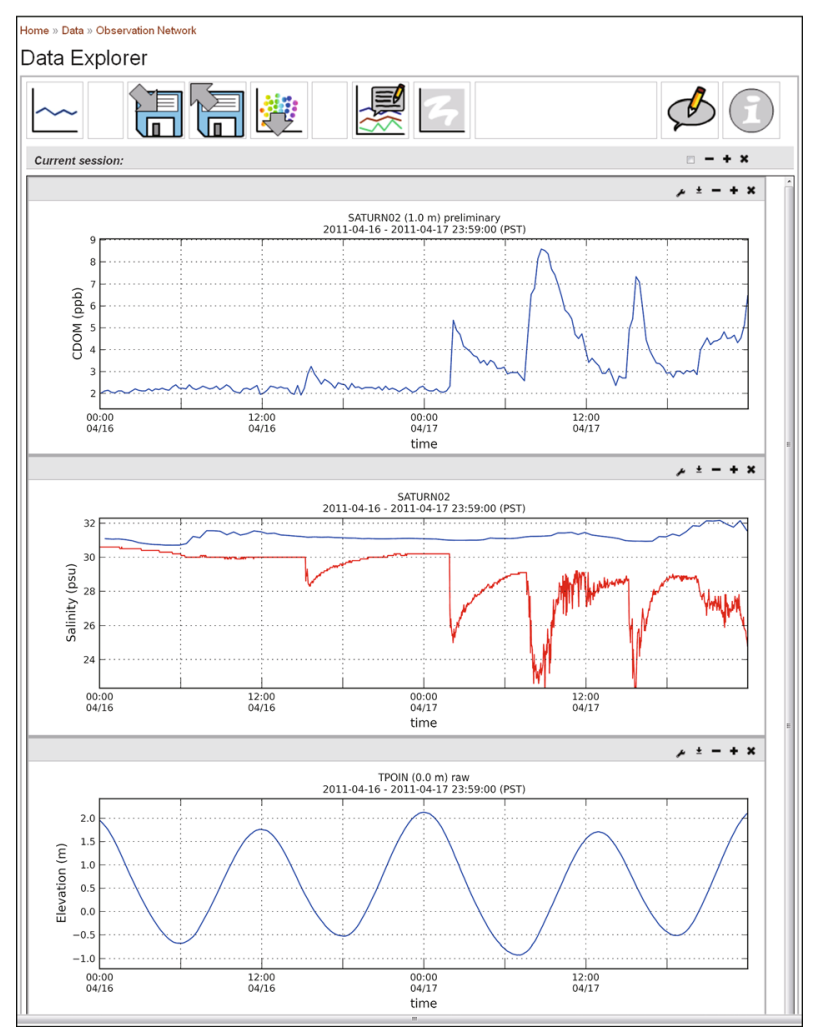

Fig. 16 Example of the exploratory use of the Data Explorer. The top panel shows, from a 1m-deep sensor, multiple CDOM fronts crossing SATURN-02 on April 16 and (more markedly) April 17, 2011. The middle panel shows salinities at $1 \mathrm{~m}$ (blue) and $35 \mathrm{~m}$ (red). The coupling of salinity and CDOM data suggest that the fronts are tied to the freshwater plume, and thus have a riverine source. The bottom panel shows that, while most fronts occur during ebb, the largest of the fronts occurs during flood - suggesting by its intensity the effective re-entrainment of water released from the river in the prior ebb or ebbs. Visualized but not shown: wind direction is approximately constant during the onset of the fronts, while wind speed has a temporary decrease. All panels are extracted directly from the Data Explorer web interface. See stccmop.org/datamart/observation_network/dataexplorer, for access to the Data Explorer. Image is a screen capture of a Data Explorer session.

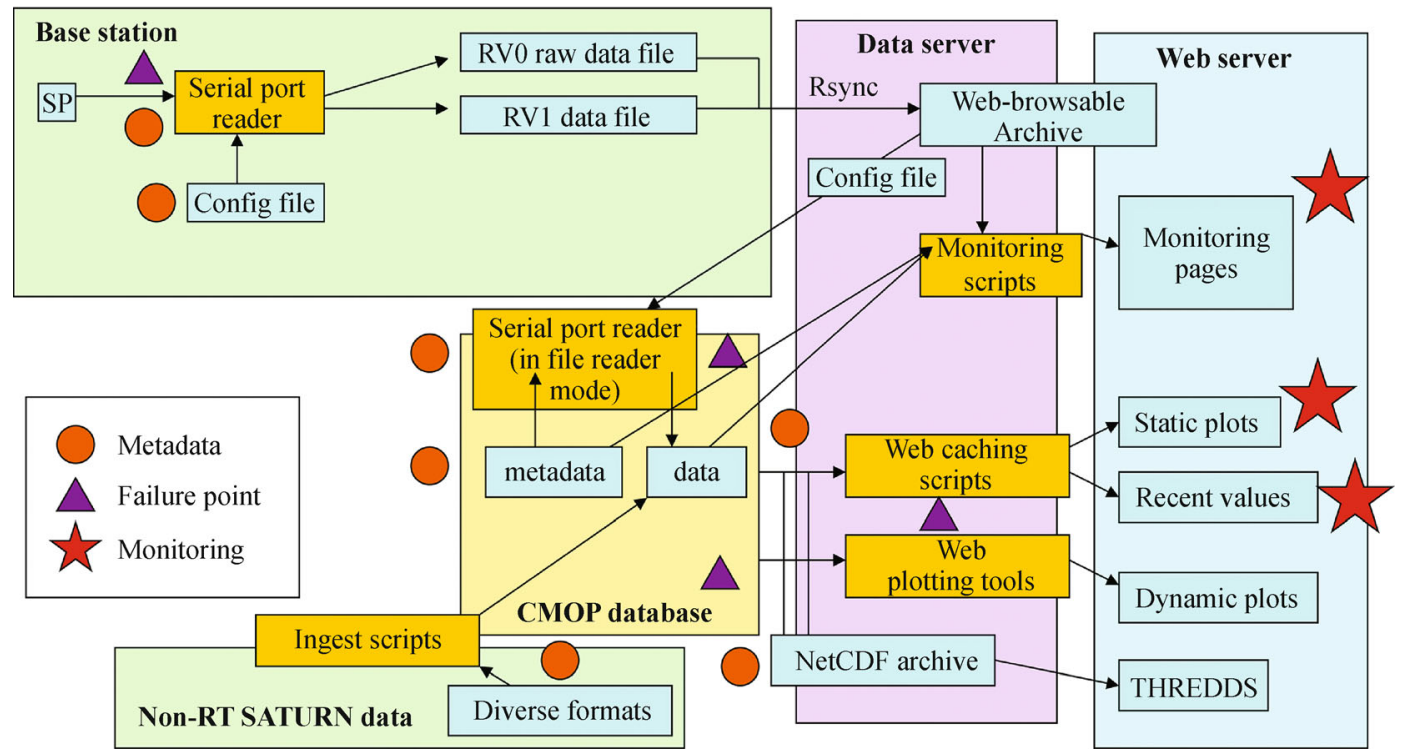

Fig. 17 Sensor data flow in real time from a wide variety of SATURN observing platforms to a central CMOP Database. Data can also flow in non real-time (non-RT) from certain CMOP platforms (e.g., ships or AUVs) or external sources. Regardless of their source, observations are imported, parsed and standardized using a common format. Researchers can access the data using diverse methods, which allow them to interactively view, combine and analyze data of interest, or to download selected data into specialized analysis tools for further study. See details in the text. 


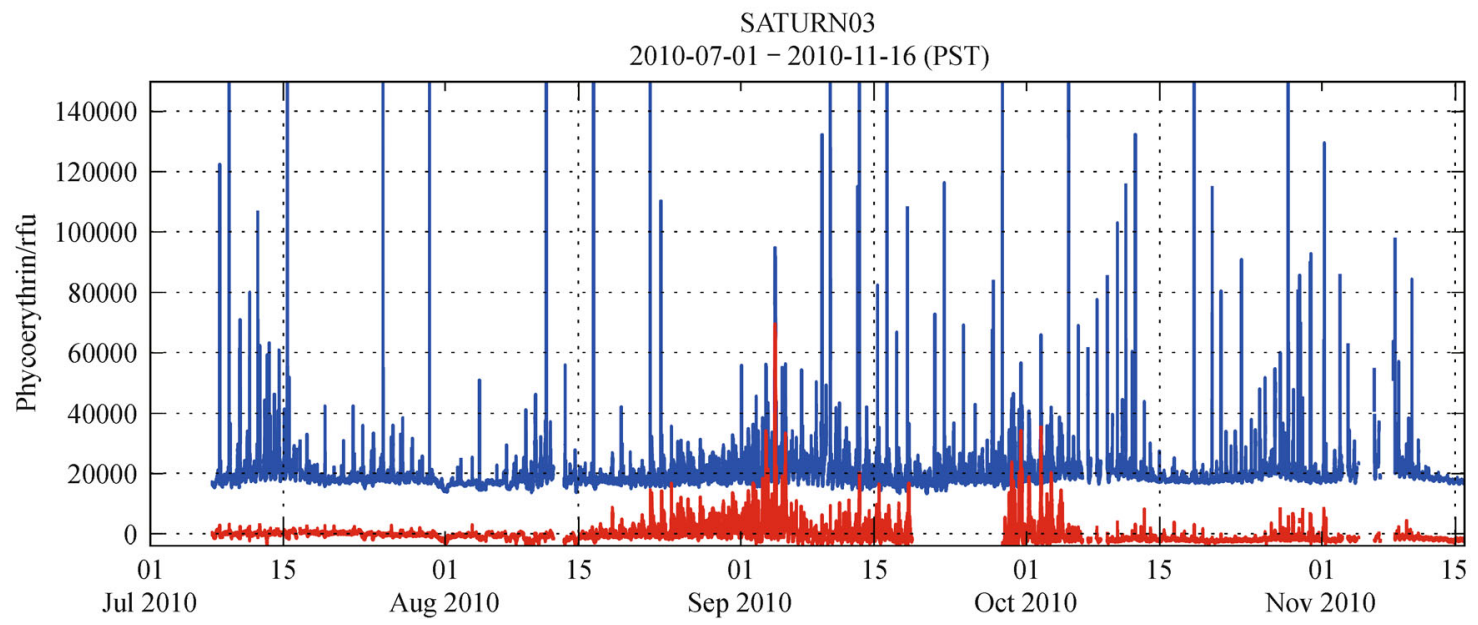

Fig. 18 The importance of quality assessment is illustrated through a time series of phycoerythrin fluorescence at SATURN-03 (from the $2.4 \mathrm{~m}$ deep pumping port) for the summer of 2010. Colors represent data quality: PD0 (blue) and PD2 (red). Quality control corrected in this case a significant artifact due to turbidity, zeroed the data and removed data from an identified period of sensor fouling. Prior to correction, the data were difficult to interpret, with the artifact masking the phycoerythrin signal. Following quality control the phycoerythrin data clearly capture the dynamics of the bloom of Mesodinium spp. and when placed in the context of dissolved oxygen data (not shown) suggest that the bloom is responsible for local super-saturation of dissolved oxygen in the estuary. Image is taken from a Data Explorer session.

climate scales of importance for estuaries, because endurance observation networks are a relatively recent concept for these ecosystems. Moreover, funding mechanisms to maintain endurance time series on a permanent basis are insufficiently established, even if the U.S. Integrated Ocean Observing System represents a step in the right direction.

In spite of these and other challenges, collaboratories such as SATURN can transform the ability to conduct hypothesis-driven science in estuaries, because the testing of hypotheses can be conducted faster, at a reduced cost and more thoroughly by leveraging the (sensed and modeled) data-rich environments that these infrastructures create. The power of collaboratories is exemplified by modern field campaigns. For instance, it is now possible with the benefit of skill-assessed modeling products to plan campaigns in silico prior to the deployment of any mobile platforms (e.g., vessels or AUVs) in the field. This capability increases the likelihood of being able to place sensors where and when needed to capture features as complex and transient as plume fronts and estuarine turbidity maxima. This capability also improves the safety of high-risk deployments, such as AUV missions in the highly energetic North Channel or across the mouth of the Columbia River. In another example, it is also possible to conduct land-based campaigns where specialized adaptive sampling (e.g., ESP sampling for RNA and DNA analyses) is triggered by features (e.g., estuarine turbidity maxima) or thresholds (e.g., oxygen-saturation levels) detected by co-located sensors or predicted by coordinated models.

The extensive data sets produced by collaboratories also open the doors for exploratory or discovery science (Hey et al., 2009) as a legitimate and effective manner to advance understanding of estuaries. For instance, multiyear simulations of circulation are fertile grounds for exploring seasonal and inter-annual patterns and trends of change, not only for circulation (e.g., characterization of estuarine regimes), but also for circulation-dependent ecosystem features, such as estuarine habitat and oceanentry conditions of juvenile salmon (Burla, 2009; Burla et al., 2010b; Miller et al., 2013, 2014). It is also possible to conduct low-cost remote research or education. As an example, it is possible for someone in, say, China, to conduct exploratory research on the Columbia River estuary - or to introduce students to estuaries using the Columbia River as reference (Green et al., 2013) — by assessing and contextualizing SATURN sensor data via tools such as the Data Explorer (e.g., Fig. 16).

Regardless of whether hypothesis-testing or exploratory analyses are preferred (or combined), the open information flows of collaboratories are particularly effective in supporting interdisciplinary team science - as illustrated by the $\sim 150$ multi-author peer-reviewed articles published since CMOP's inception in July 2006 through March 2015, with our major scientific synthesis still ahead. See stccmop.org/publications for a list of CMOP articles.

Collaboratories such as SATURN also offer exciting opportunities for technology assessment and development. For instance, rigorous modeling benchmarks based on SATURN observations (Kärnä et al., 2015) have not only improved the skill of current circulation simulation databases, but have also offered guidance on priority 
requirements for next-generation estuarine models. In another example, the development of sophisticated estuarine biogeochemical models for the Columbia River estuary has been transformed by the availability of time series from interdisciplinary sensor packages. In addition, the SATURN infrastructure has supported the development or testing of multiple sensor technologies under challenging environmental conditions (high turbidity, fluctuating salinity, etc.).

Collaboratories are also extremely effective in helping translate science into regional decision-making and management because scientists can respond quickly to requests for applied studies, and also because regional stakeholders have knowledge and even "ownership" of the development, priorities and maintenance of collaboratories. Examples of science translation to stakeholders include the CMOP contributions to the Columbia River Channel Improvement Project (Seaton et al., 2014) and to the Columbia River Treaty Review (U.S. Entity, 2013). In both cases, circulation models, skill-assessed against sensor data and linked to fisheries and other ecosystem metrics, helped build regional consensus on specific issues. In the case of the Columbia River Channel Improvement Project, the relevant issue was whether to continue postconstruction field observations of the potential impact of a recent deepening of the channel. In the case of the Columbia River Treaty Review, the relevant issue was to what extent the estuary was influenced by a set of scenarios of change in hydropower operations.

Acknowledgements This paper is dedicated to the memory of Murray Levine (1949-2013): colleague, scientist, leader, and friend. He was a Professor at Oregon State University and the co-Director of CMOP. His contributions were fundamental to CMOP's scientific paradigm and oceanographic campaigns.

Thanks are due to the broader multi-institutional and interdisciplinary team of CMOP scientists and students, and to the stakeholders of the Columbia River basin (including universities, state and federal agencies and tribes). Special thanks are due to the Clatsop Community College for hosting the CMOP field station in Astoria and enabling CMOP's use of the M/V Forerunner; and to the host entities for our endurance stations, in particular Oregon Department of Transportation (SATURN-01 and 09), Point Adams Packing Company (SATURN-03), Tongue Point Job Corp (SATURN-04) and U.S. Coast Guard (multiple stations).

Within CMOP, special thanks are due to all past and present members of the CMOP operational teams: the Astoria field team, cyber-infrastructure team and modeling team. Of particular note: in the Astoria field team, (former member) Katie Rathmell for leading coastal glider operations and Jo Goodman for her work in SATURN station maintenance and instrument cross-comparison; in the cyber-infrastructure team, former member Alex Jaramillo for leading the development of the Data Explorer; and in the modeling team, former member Dr. Joseph Zhang (now at Virginia Institute of Marine Sciences) for an instrumental role in the early development of the Virtual Columbia River. Special thanks are also due to the AUV team members Dr. Andrey Shcherbina and Trina Litchendorf; the SeaFlow team, especially Dr. François Ribalet; Ethan VanMatre for his contributions to the SWAP telemetry; Drs. Thomas Sanford (University of Washington), Fred Prahl and Jim Lerczak (Oregon State University) and Curtis Roegner (NOAA) for leading land-based and vessel-based field campaigns; Dr. Alexandra Cravo (Universidade do Algarve, Portugal) for many thoughtful suggestions; and Amy Johnson, CMOP Managing director - and, before her,
Phil Barrett - for coordinating licenses and permits for the SATURN stations. Special thanks are also due to Bonnie Gibbs for thorough proofreading of the manuscript. Finally, special thanks are due to the captains and crew of all the vessels - from UNOLS, Clatsop Community College and Quinault Indian Nation - used by CMOP, without whom our shipboard science, and AUV and glider deployments, would not have been possible.

The U.S. National Science Foundation (OCE-0424602) has provided primary support for CMOP's exploration of new scientific paradigms for estuarine understanding and prediction. Stakeholders of the Columbia River provided additional motivation and support; thanks are due in particular to the National Oceanic and Atmospheric Administration, the U.S. Army Corps of Engineers, the Bonneville Power Administration, the Columbia River InterTribal Fish Commission, the Unites States Geological Survey, the Lower Columbia River Estuary Partnership and the U.S. Entity for the Columbia River Treaty Review. Simulation databases and supporting observations are an integral part of SATURN, a CMOP-maintained sub-system of Northwest Association of Networked Ocean Observing Systems (NANOOS), the Pacific Northwest arm of the U.S. Integrated Ocean Observing System (IOOS). This work used the Extreme Science and Engineering Discovery Environment, XSEDE (Towns et al., 2014), which is supported by National Science Foundation grant number ACI-1053575.

\section{References}

Anderson C R, Davis R E, Bandolin N S, Baptista A M, Tebo B M (2011). Analysis of in situ manganese (II) oxidation in the Columbia River and offshore plume: linking Aurantimonas and the associated microbial community to an active biogeochemical cycle. Environ Microbiol, 13(6): 1561-1576

Baptista A M (2006). CORIE: the first decade of a coastal margin collaborative observatory. In: Proceedings of MTS/IEEE Oceans '06. Boston, Massachusetts: IEEE, 1-6

Baptista A M (2015). The power of estuarine collaboratories: can lessons learned in the Columbia River inform a global vision? In: Proceedings of IEEE/OES Underwater Technologies 2015. Chennai, India: IEEE/OES, 1-7

Baptista A M, Howe B, Freire J, Maier D, Silva C (2008). Scientific exploration in the era of ocean observatories. Comput Sci Eng, 10(3): 53-58

Baptista A M, Wilkin M, Pearson P, Turner P J, McCandlish C, Barrett P (1999). Coastal and estuarine forecast systems: a multi-purpose infrastructure for the Columbia River. Earth Syst Monit, 9(3): 1-2, 45,16

Baptista A M, Zhang Y L, Chawla A, Zulauf M, Seaton C, Myers E P III, Kindle J, Wilkin M, Burla M, Turner P J (2005). A cross-scale model for 3D baroclinic circulation in estuary-plume-shelf systems: II. application to the Columbia River. Cont Shelf Res, 25(7-8): 935-972

Barbier E B, Hacker S D, Kennedy C, Koch E W, Stier A C, Silliman B $\mathrm{R}$ (2011). The value of estuarine and coastal ecosystem services. Ecol Monogr, 81(2): 169-193

Barnes C A, Duxbury A C, Morse B A (1972). Circulation and selected properties of the Columbia River effluent at sea. In: Pruter A T, Alverson D L, eds. The Columbia River Estuary and Adjacent Ocean Waters. Seattle: University of Washington Press, 41-80

Bottom D L, Simenstad C A, Baptista A M, Burke J, Jay D A, Burke J, Jones K K, Casillas E, Schiewe M H (2005). Salmon at river's end: the role of the estuary in the decline and recovery of Columbia River salmon. NOAA Technical memorandum NMFS-NWFSC-68 
Bräuer S L, Adams C, Kranzler K, Murphy D, Xu M, Zuber P, Simon H M, Baptista A M, Tebo B M (2011). Culturable Rhodobacter and Shewanella species are abundant in estuarine turbidity maxima of the Columbia River. Environ Microbiol, 13(3): 589-603

Bräuer S L, Kranzler K, Goodson N, Murphy D, Simon H M, Baptista A M, Tebo B M (2013). Dark carbon fixation in the Columbia River's estuarine turbidity maxima: molecular characterization of red-type cbbL genes and measurement of DIC uptake rates in response to added electron donors. Estuaries Coasts, 36(5): 1073-1083

Burke B J, Anderson J J, Baptista A M (2014). Evidence for multiple navigational sensory capabilities by Chinook salmon. Aquat Biol, 20 (1): $77-90$

Burla M (2009). The Columbia River estuary and plume: natural variability, anthropogenic change and physical habitat for salmon. Dissertation for Ph.D Degree. Beaverton, Oregon: Oregon Health \& Science University

Burla M, Baptista A M, Casillas E, Williams J G, Marsh D M (2010b). The influence of the Columbia River plume on the survival of steelhead (Oncorhynchus mykiss) and Chinook salmon (Oncorhynchus tshawytscha): a numerical exploration. Can J Fish Aquat Sci, 67(10): 1671-1684

Burla M, Baptista A M, Zhang Y, Frolov S (2010a). Seasonal and interannual variability of the Columbia River plume: a perspective enabled by multiyear simulation databases. Journal of Geophysical Research. Oceans, 115(C2): C00B16

Chawla A, Jay D A, Baptista A M, Wilkin M, Seaton C (2008). Seasonal variability and estuary-shelf interactions in circulation dynamics of a river-dominated estuary. Estuaries Coasts, 31(2): 269-288

DeLorenzo S, Bräuer S L, Edgmont C A, Herfort L, Tebo B M, Zuber P (2012). Ubiquitous dissolved inorganic carbon assimilation by marine heterotrophic bacteria in the Pacific Northwest coastal ocean as determined by stable isotope probing. PLoS ONE, 7(10): e46695

Diaz R J, Rosenberg R (2008). Spreading dead zones and consequences for marine ecosystems. Science, 321(5891): 926-929

Durkin C A, Bender S J, Chan K Y K, Gaessner K, Grunbaum D, Armbrust E V (2013). Silicic acid supplied to coastal diatom communities influences cellular silicification and the potential export of carbon. Limnol Oceanogr, 58(5): 1707-1726

Evans W, Hales B, Strutton P G (2013). $\mathrm{PCO}_{2}$ distributions and airwater $\mathrm{CO}_{2}$ fluxes in the Columbia River estuary. Estuar Coast Shelf Sci, 117: 260-272

Fortunato C S, Crump B C (2011). Bacterioplankton community variation across river to ocean environmental gradients. Microb Ecol, 62(2): 374-382

Fortunato C S, Eiler A, Herfort L, Needoba J A, Peterson T D, Crump B $C$ (2013). Determining indicator taxa across spatial and seasonal gradients in the Columbia River coastal margin. ISME J, 7(10): 1899-1911

Fortunato C S, Herfort L, Zuber P, Baptista A M, Crump B C (2012). Spatial variability overwhelms seasonal patterns in bacterioplankton communities across a river to ocean gradient. ISME J, 6(3): 554-563

Frolov S, Baptista A M, Wilkin M (2008). Optimizing fixed observational assets in a coastal observatory. Cont Shelf Res, 28 (19): 2644-2658
Gilbert M, Needoba J A, Koch C, Barnard A, Baptista A M (2013). Nutrient loading and transformations in the Columbia River estuary determined by high resolution in situ sensors. Estuaries Coasts, 36(4): 708-727

Green V, Watts N B, Wegner K, Thompson M, Johnson A, Peterson T, Baptista A M (2013). Coastal margin science and education in the era of collaboratories. Current, 28(3): 27-31

Herfort L, Peterson T D, Campbell V, Futrell S, Zuber P (2011a). Myrionecta rubra (Mesodinium rubrum) bloom initiation in the Columbia River estuary. Estuar Coast Shelf Sci, 95(4): 440-446

Herfort L, Peterson T D, McCue L A, Crump B C, Prahl F G, Baptista A M, Campbell V, Warnick R, Roegner G C, Zuber P (2011b). Myrionecta rubra population genetic diversity and its cryptophyte chloroplast specificity in recurrent red tides in the Columbia River estuary. Aquat Microb Ecol, 62(1): 85-97

Herfort L, Peterson T D, McCue L A, Zuber P (2011c). Protist 18S rRNA gene sequence analysis reveals multiple sources of organic matter contributing to turbidity maxima of the Columbia River estuary. Mar Ecol Prog Ser, 438: 19-31

Herfort L, Peterson T D, Prahl F G, McCue L A, Needoba J A, Crump B C, Roegner G C, Campbell V, Zuber P (2012). Red waters of Myrionecta rubra are biogeochemical hotspots for the Columbia River estuary with impacts on primary/secondary productions and nutrient cycles. Estuaries Coasts, 35(3): 878-891

Herfort L, Seaton C, Wilkin M, Seitz K, Lopez J, Smith M, Haynes V, Baptista A M, Simon H M. Autonomous adaptive sampling of microbial processes in a dynamic estuary. Limnol Oceanogr Methods, (in press)

Hey T, Tansley S, Tolle K, eds. (2009). The Fourth Paradigm-DataIntensive Scientific Discovery. Berlin, Heidelberg: Springer

Hickey B M, Kudela R M, Nash J D, Bruland K W, Peterson W T, MacCready P, Lessard E J, Jay D A, Banas N S, Baptista A M, Dever E P, Kosro P M, Kilcher L K, Horner-Devine A R, Zaron E D, McCabe R M, Peterson J O, Orton P M, Pan J, Lohan M C (2010). River influences on shelf ecosystems: introduction and synthesis. Journal of Geophysical Research, 115(2): C00B17

Howarth R, Chan F, Conley D J, Garnier J, Doney S C, Marino R, Billen G (2011). Coupled biogeochemical cycles: eutrophication and hypoxia in temperate estuaries and coastal marine ecosystems. Front Ecol Environ, 9(1): 18-26

HSBC (2012). Exploring the links between water and economic growth. A report prepared for HSBC by Frontier Economics: Executive Summary

IPCC (2014). Climate change 2014: impacts, adaptation, and vulnerability. Part B: regional aspects. Contribution of Working Group II to the Fifth Assessment Report of the Intergovernmental Panel on Climate Change. Cambridge, United Kingdom and New York, USA

Kahn P, Herfort L, Peterson T D, Zuber P (2014). Discovery of a Katablepharis $s p$. in the Columbia River estuary that is abundant during the spring and bears a unique large ribosomal subunit sequence element. MicrobiologyOpen, 3(5): 764-776

Kärnä T, Baptista A M, Lopez J E, Turner P J, McNeil C, Sanford T B (2015). Numerical modeling of circulation in high-energy estuaries: a Columbia River Estuary benchmark. Ocean Model, 88: 54-71

Lave J, Wenger E (1991). Situated Learning: Legitimate Peripheral Participation. Cambridge: Cambridge University Press 
Liu Y, MacCready P, Hickey B M (2009). Columbia River plume patterns in summer 2004 as revealed by a hindcast coastal ocean circulation model. Geophys Res Lett, doi: 10.1029/2008GL036447

Lopez J E, Brown J (2014). Improving the performance of the coastal ocean model SELFE. In: SIAM Conference on Parallel Processing for Scientific Computing, Portland, Oregon

Lopez J, Baptista A M, Spitz Y (2012). Modeling estuarine turbidity maxima in the Columbia River estuary. In: 2012 Columbia River Estuary Conference: New Scientific Findings and their Management Implications. Astoria, Oregon, US

Lotze H K, Lenihan H S, Bourque B J, Bradbury R H, Cooke R G, Kay M C, Kidwell S M, Kirby M X, Peterson C H, Jackson J (2006). Depletion, degradation, and recovery potential of estuaries and coastal seas. Science, 312(5781): 1806-1809

Maier M A, Peterson T D, Needoba J A, Bartowicz K, Baptista A M (2012). Phytoplankton seasonal dynamics and ecological interactions in the lower Columbia River. In: AGU Ocean Sciences Meeting, Salt Lake City, Utah

MEA (2005). Ecosystems and human well-being: current state and trends: findings of the Condition and Trends Working Group of the Millennium Ecosystem Assessment. Washington D C: Island Press

Megler V M, Maier D (2013). Data near here: bringing relevant data closer to scientists. Comput Sci Eng, 15(3): 44-53

Miller J A, Teel D J, Peterson W T, Baptista A M (2014). Assessing the relative importance of local and regional processes on the survival of a threatened salmon population. PLoS ONE, 9(6): e99814

Miller J A, Teel D, Baptista A M, Morgan C, Bradford M (2013). Disentangling bottom-up and top-down effects on survival during early ocean residence in a population of Chinook salmon. Can J Fish Aquat Sci, 70(4): 617-629

NOAA (2014a), U.S. population living in coastal watershed counties, in NOAA's State of the Coast

NOAA (2014b), The coast - our nation's economic engine, in NOAA's State of the Coast

NSF (2005). Ocean Observatories Initiative. Science Plan Report

OGE (2014). Our Global Estuary: U.S. National Workshop, October $21-$ 23, 2013. Editor: M. Davis. Harbor Branch Oceanographic Institute, Harbor Branch, FL, USA

Peterson T D, Golda R L, Garcia M L, Li B, Maier M A, Needoba J A, Zuber P (2013). Associations between Mesodinium rubrum and cryptophyte algae in the Columbia River estuary. Aquat Microb Ecol, 68(2): 117-130

Pinto L, Fortunato A B, Zhang A, Oliveira A, Sancho F E P (2012). Development and validation of a three-dimensional morphodynamic modelling system for non-cohesive sediments. Ocean Model, 57- 58 (C): $1-14$

Rathmell K, Wilkin M, Welle P, Mattson T, Baptista A M (2013). A Very Smart Kayak. Current: The Journal of Marine Education, 28(3): 3233

Robinson P, Leight A K, Trueblood D D, Wood B (2013). Climate sensitivity of the national estuarine research reserve system. NOAA Special Report

Roegner C G, Needoba J A, Baptista A M (2011b). Coastal upwelling supplies oxygen-depleted water to the Columbia River estuary. PLoS ONE, 6(4): e18672

Roegner G C, Seaton C, Baptista A M (2011a). Climatic and tidal forcing of hydrography and chlorophyll concentrations in the Columbia River estuary. Estuaries Coasts, 34(2): 281-296

Scholin C A (2013). Ecogenomic sensors. In: Levin S A, eds. Encyclopedia of Biodiversity. Waltham, Massachusetts: Academic Press, 690-700

Seaton C, Turner P J, Kärnä T, Baptista A M (2014). Columbia River channel improvement project. Post-project analysis. Final Report to the U.S. Army Corps of Engineers, Portland, Oregon: Oregon Health \& Science University

Simmons S, Casavant K (2010). Historical waterborne commerce on the Columbia-Snake River system: commodity movements up and down river, 1991-2010. Freight Policy Transportation Institute, Pullman, Washington, Washington State University

Smith M W, Allen L Z, Allen A E, Herfort L, Simon H M (2013). Contrasting genomic properties of free-living and particle-attached microbial assemblages within a coastal ecosystem. Front Microbiol, 4: 120

Smith M W, Herfort L, Tyrol K, Sucui D, Campbell V, Crump B C, Peterson T D, Zuber P, Baptista A M, Simon H M (2010). Seasonal changes in bacterial and archaeal gene expression patterns across salinity gradients of the Columbia River coastal margin. PLoS ONE, 5(10): e13312

Smith M W, Maier M, Suciu D, Peterson T D, Bradstreet T, Nakayama J, Simon H M (2012). High resolution microarray assay for rapid taxonomic assessment of Pseudo-nitzschia spp. (Bacillariophyceae) in the field. Harmful Algae, 19: 169-180

Spitz Y H (2011). Ecosystem modeling of the Oregon shelf: everything but the kitchen sink. In: Omori K, Guo X, Yoshie N, Fujii N, Handoh I C, Isobe A, Tanabe S, eds. Interdisciplinary Studies on Environmental Chemistry-Marine Environmental Modeling \& Analysis. TERRAPUB, 1-9

Spitz Y H, Moisan J R, Abbott M R (2001). Configuring an ecosystem model using data from the Bermuda Atlantic time series (BATS). Deep Sea Res Part II Top Stud Oceanogr, 48(8-9): 1733-1768

Statham P J (2012). Nutrients in estuaries-An overview and the potential impacts of climate change. Sci Total Environ, 434: 213-227

Swalwell J E, Ribalet F, Armbrust E V (2011). SeaFlow: a novel underway flow-cytometer for continuous observations of phytoplankton in the ocean. Limnol Oceanogr Methods, 9(October): 466477

Towns J, Cockerill T, Dahan M, Foster I, Gaither K, Grimshaw A, Hazlewood V, Lathrop S, Lifka D, Peterson G D, Roskies R, Scott J R, Wilkens-Diehr N (2014). XSEDE: accelerating scientific discovery. Computing in Science \& Engineering, 16(5): 62-74

U.S. Entity (2013). Regional recommendation for the future of the Columbia River Treaty after 2024. http://www.crt2014-2024review. gov/Files/Regional Recommendation Final, 13 DEC 2013.pdf

Wenger E (1998). Communities of Practice: Learning, Meaning, and Identity. Cambridge: Cambridge University Press

Zhang Y, Baptista A M (2008). SELFE: a semi-implicit Eulerian Lagrangian Finite-element model for cross-scale ocean circulation. Ocean Model, 21(3-4): 71-96

Zhang Y, Baptista A M, Myers E P (2004). A cross-scale model for 3D baroclinic circulation in estuary-plume-shelf systems: I. formulation and skill assessment. Cont Shelf Res, 24(18): 2187-2214 


\section{AUTHOR BIOGRAPHIES}

António M. Baptista has a B.Sc. in Civil Engineering from Academia Militar, Portugal and M.Sc. and Ph.D. degrees in Civil Engineering from the Massachusetts Institute of Technology, United States. He is a Professor at the Oregon Health \& Science University, U.S. and serves as the Director of the Center for Coastal Margin Observation \& Prediction, a multi-institutional Science and Technology Center funded by the National Science Foundation. Prof. Baptista's research is broadly interdisciplinary, anchored on a core expertise in estuarine science and in observation \& modeling systems. He has published about 70 peerreviewed articles, often collaboratively, in areas including computational science; physical, biogeochemical \& microbial oceanography; fisheries; natural hazards; and computer science. He provides scientific and operational coordination for the SATURN collaboratory. E-mail: baptista@ohsu.edu.

Charles Seaton has a B.Sc. in Botany from the University of Massachusetts at Amherst and a M.S. in Environmental Science and Engineering from the Oregon Graduate Institute of Science \& Technology. He is a Research Associate at the Oregon Health \& Science University, U.S., and the coordinator of the cyber-infrastructure team for the Center for Coastal Margin Observation \& Prediction. Mr. Seaton has published 9 peer-reviewed articles. E-mail: seatonc@ohsu.edu.

Michael P. Wilkin has a B.Sc. in Oceanography from University of Southampton, United Kingdom. With over 25 years of experience in the design and deployment of oceanographic instrumentation, he is a Senior Research Associate at Oregon Health \& Science University, U.S., and manages the design, implementation and maintenance of the estuarine and coastal elements of the SATURN observation network from a field station in Astoria, Oregon, U.S. Mr. Wilkin has published 10 peerreviewed articles. Email: wilkin@stccmop.org.

Sarah F. Riseman has a B.Sc. in Zoology from the University of Massachusetts, U.S., and a M.Sc. in Marine Biology from the College of Charleston, U.S. She is a Research Associate at Oregon Health \& Science University, U.S., working on quality assurance and quality control of biogeochemical data for the Center for Coastal Margin Observation \& Prediction. Before joining the center in 2010, she had over 10 years of oceanographic research experience including operation and maintenance of a diversity of instrumentation for biogeochemical measurements and over 13 cumulative months of research at sea or in remote field locations. She has published 13 peer-reviewed articles. Email: risemans@stccmop.org.

Joseph A. Needoba has a B.Sc. (Biology) degree and a Ph.D. (Botany) degree from the University of British Columbia, Canada. He is an Assistant Professor at Oregon Health \& Science University, U.S, and an Investigator in the Center for Coastal Margin Observation \& Prediction. He has published more than 20 peer-reviewed papers in the fields of oceanography and estuarine science. E-mail: needobaj@ohsu.edu.

David Maier is Maseeh Professor of Emerging Technologies in the Department of Computer Science at Portland State University, U.S. His research interests include scientific information management, datastream systems, superimposed information and declarative cloud programming. Prof. Maier has a dual BA (Honors College) in Mathematics and Computer Science from the University of Oregon, U. S. and a Ph.D. in Electrical Engineering and Computer Science from Princeton University, U.S. He is an ACM Fellow, a Senior Member of IEEE and a member of SIAM. He has published 95 peer-reviewed articles in journals and selective conferences. He is a member of the CMOP cyber-infrastructure team. Email: maier@cs.pdx.edu.

Paul J. Turner has a B.Sc in Mathematics from Boise State University. $\mathrm{He}$ is a Senior Research Assistant at the Oregon Health \& Science University, U.S. As a member of the cyber-infrastructure team, he manages operational details of the Virtual Columbia River for the Center for Coastal Margin Observation \& Prediction. He has published 9 peerreviewed articles. E-mail: turnerpa@ohsu.edu.

Tuomas Kärnä has a M.Sc in Technology from Helsinki University of Technology, Finland and a Ph.D. in Applied Mathematics from Université Catholique de Louvain, Belgium. He is a Post-Doctoral Fellow at the Oregon Health \& Science University, U.S. He has published 14 peer-reviewed articles. E-mail:karna@ohsu.edu.

Jesse E. Lopez has a B.A. in History from the University of Washington, U.S. He is a Ph.D. candidate at the Oregon Health \& Science University, U.S. and a Department of Energy Computational Science Graduate Fellow. Email: lopezjes@ohsu.edu.

Lydie Herfort received an undergraduate diplomat (D.E.U.G.) in Biology from the University of Caen, France, and a third year of B.Sc. and a Ph.D. degree in aquatic biology from Queen Mary University London, United Kingdom. She is a Senior Research Associate at the Center for Coastal Margin Observation \& Prediction at Oregon Health \& Science University, U.S. Dr. Herfort studies the ecology and physiology of aquatic microorganisms - specifically bacteria, archaea and protists - to assess their impacts on biogeochemical cycles. Her work involves many aspects of SATURN's collaboratory, including traditional vessel-based campaigns and adaptive microbial water sample collection with an Environmental Sample Processor. She has published 23 peerreviewed articles. E-mail: herfort@ohsu.edu.

V.M. Megler is a Post-Doctoral Fellow in Computer Science at Portland State University, U.S., having received a Ph.D. there in 2015. Megler's most recent industry position was as Executive IT Architect at IBM, publishing more than 20 industry technical papers on applications of emerging technologies to industry problems. Current research centers on applying Information Retrieval techniques to scientific data, ranging from oceanographic to genomic data. General research interests include applications of emerging technologies, scientific information management and spatio-temporal databases. Megler has 11 peer-reviewed research articles and holds 2 patents. Email: vmegler@cs.pdx.edu.

Craig McNeil has a B.Sc. in physics from Heriot-Watt University, Scotland and a Ph.D. from University of Victoria, Canada. He is a Principal Oceanographer at the Applied Physics Laboratory at the 
University of Washington, U.S. His multi-disciplinary research focuses on upper ocean processes and interactions. He has published more than 20 peer-reviewed articles. He coordinates the CMOP autonomous underwater vehicles program. E-mail: cmcneil@apl.washington.edu.

Byron C. Crump has a M.S. and Ph.D. in Oceanography from the University of Washington, U.S. He is an Associate Professor in Ocean Ecology and Biogeochemistry at the College of Earth, Ocean and Atmospheric Sciences, Oregon State University, U.S. His research explores the ecology, biodiversity and genomics of microbes in lakes, rivers, estuaries and coastal oceans. He has published 55 peer-reviewed articles and is an editor for the textbook Estuarine Ecology $2^{\text {nd }} E d$. (Wiley Interscience). E-mail: bcrump@coas.oregonstate.edu.

Tawnya D. Peterson has a B.Sc. in Biology from Mount Allison University (Sackville, Canada) and a Ph.D. in Oceanography from the University of British Columbia (Vancouver, Canada). She is an Assistant Professor at Oregon Health \& Science University, U.S., and an Investigator in the Center for Coastal Margin Observation \& Prediction. She has published over 30 peer-reviewed papers in the fields of oceanography and environmental science. E-mail: petertaw@ohsu.edu.

Yvette H. Spitz has a B.Sc. in Physics and a M.Sc. in Oceanography from the University of Liège, Belgium, a M.Sc. in Physical
Oceanography from Florida State University, U.S., and a Ph.D. in Oceanography from Old Dominion University, U.S. She is a Professor in Ocean Ecology and Biogeochemistry at the College of Earth, Ocean and Atmospheric Sciences at Oregon State University, U.S., and has served for the last two years as co-director of the Center for Coastal Margin Observation \& Prediction. Her research includes ecosystem dynamics and physical-biological interactions in the world ocean, with ecosystem modeling spanning tropical microbes to ice algae. She is an expert in data assimilation applied to coupled circulation and ecosystem models. She has published $\sim 45$ peer-reviewed articles in areas including circulation and biogeochemical models from coastal to open ocean and ice cover ocean; particle filter and variational adjoint data assimilation. E-mail: yspitz@coas.oregonstate.edu.

Holly M. Simon has B.S. (Biology) and B.A. (Chemistry) degrees from the Metropolitan State College of Denver, U.S., and a Ph.D. degree (Bacteriology) from the University of Wisconsin at Madison, U.S. She is an Associate Professor in the Institute of Environmental Health and an Investigator in the Center for Coastal Margin Observation \& Prediction at Oregon Health \& Science University, U.S. She has published over 20 peer-reviewed articles across diverse areas of environmental microbiology, with emphasis on the application of gene sensing technologies to assess the provisioning of, and perturbations to, microbial ecosystem services. E-mail: simonh@ohsu.edu. 